\title{
Argentina: Detailed Assessment of Observance of Principles for Insurance Supervision
}

This paper was prepared based on the information available at the time it was completed in October 2011. The views expressed in this document are those of the staff team and do not necessarily reflect the views of the government of Argentina or the Executive Board of the IMF.

The policy of publication of staff reports and other documents by the IMF allows for the deletion of market-sensitive information.

Copies of this report are available to the public from

International Monetary Fund • Publication Services

700 19th Street, N.W. • Washington, D.C. 20431

Telephone: (202) 623-7430 • Telefax: (202) 623-7201

E-mail: publications@imf.org • Internet: http://www.imf.org

\section{International Monetary Fund Washington, D.C.}




\section{ARGENTINA}

\section{PRINCIPLES FOR INSURANCE SUPERVISION \\ DETAILED ASSESSMENT OF OBSERVANCE}

OCTOBER 2011

INTERNATIONAL MONETARY FUND MONETARY AND CAPITAL MARKETS DEPARTMENT
THE WORLD BANK

FINANCIAL AND PRIVATE SECTOR DEVELOPMENT VICE PRESIDENCY LATIN AMERICA AND CARIBBEAN REGIONAL VICE PRESIDENCY 


\section{Glossary}

\begin{tabular}{|l|l|}
\hline SSN & Superintendence of Insurance \\
\hline BCRA & Central bank of Argentina \\
\hline FSAP & Financial Sector Assessment Program \\
\hline IAIS & International Association of Insurance \\
\hline IFRS & International Financial Reporting Standards \\
\hline MoU & Memorandum of Understanding \\
\hline MECON & Ministry of Economy and Public Finance \\
\hline FIU & Financisl Investigation Unit \\
\hline
\end{tabular}




\section{TABle of Content}

I. INFORMATION AND METHODOLOGY USED FOR THE ASSESSMENT ..........................................

II. INSTITUTIONAL AND MACRo PRUDENTIAL SETTING ..........................................................

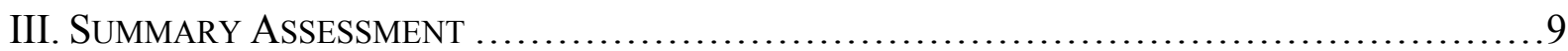

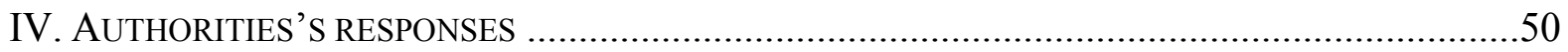

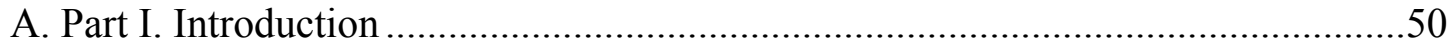

B. Part. II. Detailed response to the principles adherence assessment. ........................55 


\section{I. INFORMATION AND METHODOLOGY USED FOR THE ASSESSMENT}

1. This assessment focused on the Superintendencia de Seguros de la Nación (SSN) in Argentina. SSN has responsibility for regulation and supervision of all players in the insurance market. In addition to its role as a supervisor, SSN has powers to issue regulations, is responsible for advising the Executive on issues related to insurance, and can propose draft bills. The Laws are passed by the National Legislative Branch and enacted by the National Executive Brach.

2. The assessment was performed using the 2007 version of the Core Principles for Insurance Supervision issued by the International Association of Insurance Supervisors (IAIS).

3. In preparation for the FSAP mission, SSN staff prepared a thorough self-assessment against the ICPs. They also provided details in response to a questionnaire sent to them by the mission team in advance.

4. The mission received full cooperation from all parties contacted and team members would like to express their appreciation to the staff of the Superintendencia de Seguros de la Nación for the extensive cooperation and friendly courtesies extended to them.

\section{II. Institutional AND Macro Prudential Setting}

\section{Market overview}

5. The Argentina insurance market is the 24 th largest in the world with 0.49 percent of global non-life premiums, and the fourth largest in Latin America after Brazil, Mexico and Venezuela. Total premium to GDP stood at 2.8 percent in 2010 , with 0.5 percent for the life insurance and 2.2 percent for non life insurance segments. Although insurance premium grew for the fourth consecutive year at double digit rates, it is still low. In 2010, 2.8 per cent of the gross domestic product is spent on insurance in Argentina by comparison with Brazil, Chile, and Venezuela (in $20103.1,4$ and 3.5, respectively). The low penetration ratio indicates a high potential for growth.

Chart 1: Insurance Penetration, Life

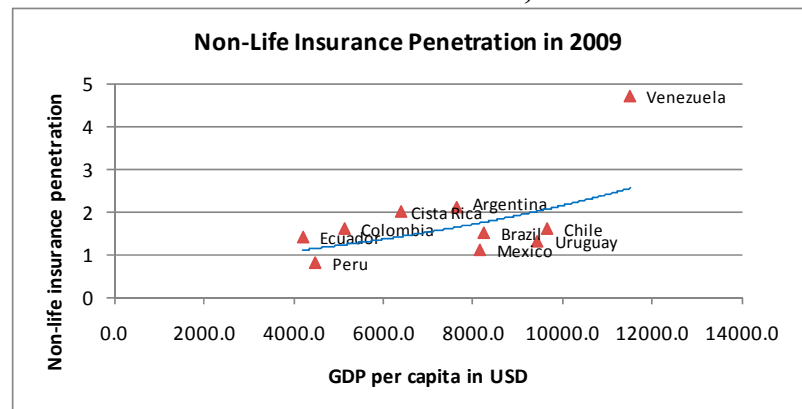

Chart 2: Insurance Penetration, Non-Life

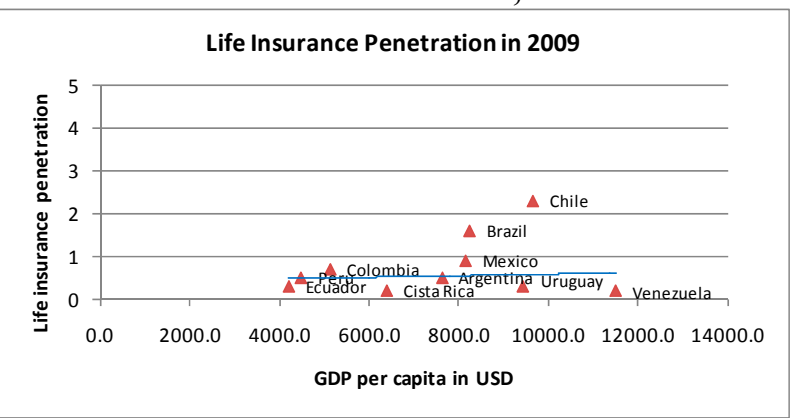

Source: SSN 
Chart 3: Insurance premium \% GDP Chart 4: Direct Premium Income
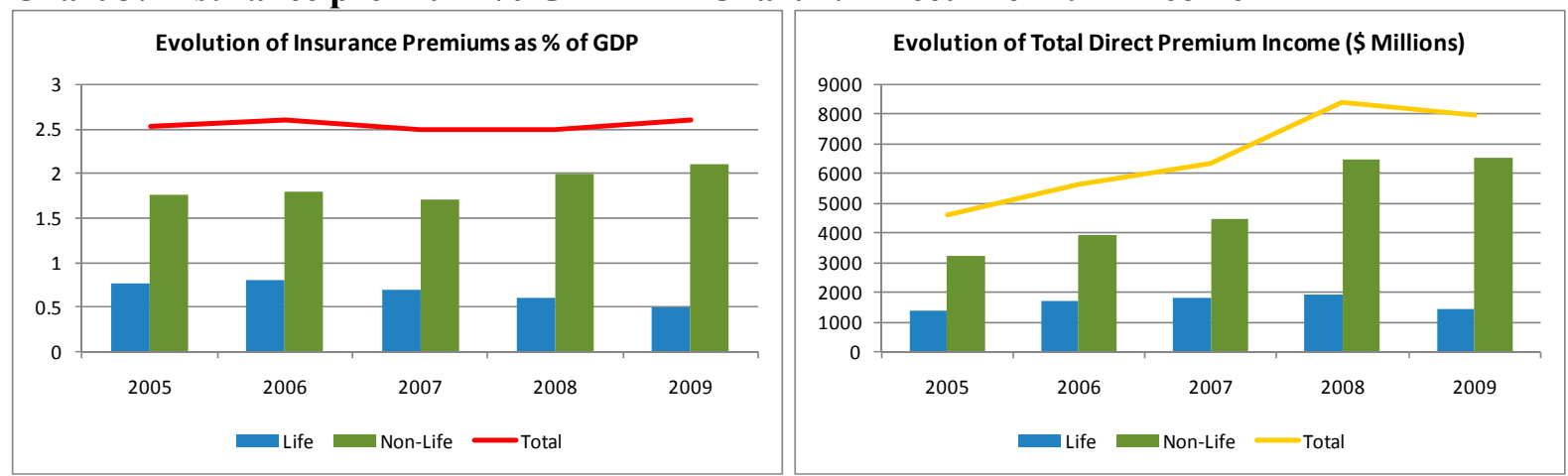

Source: $S S N$

6. Argentina's insurance market is fragmented, comprising $\mathbf{1 0 0}$ active non-life companies, including 17 specialist workers' compensation insurers and several small niche players. Many of the multinational insurance groups are present in the market, with about 40 percent of the non-life premiums. Most of the main players are local insurers, including seven of the top 10 in 2010. The market is highly competitive. Product pricing and distribution competition is fierce, in particular in the Motor segment, especially in Motor Third Party Liability (MTPL) insurance.

\section{Chart 5: Insurance Companies and Premiums}

$20062007 \quad 2008$

\begin{tabular}{|c|c|c|c|c|c|}
\hline & 2006 & 2007 & 2008 & 2009 & \\
\hline \multirow{6}{*}{$\begin{array}{l}\text { Number of insurance companies } \\
\text { Non-life or composite } \\
\text { Life } \\
\text { Retirement } \\
\text { Workers' compensation } \\
\text { Public passanger transportation }\end{array}$} & 189 & 184 & 183 & 178 & 181 \\
\hline & 99 & 96 & 98 & 99 & 100 \\
\hline & 45 & 46 & 44 & 38 & 38 \\
\hline & 23 & 23 & 22 & 21 & 21 \\
\hline & 16 & 14 & 14 & 15 & 17 \\
\hline & 5 & 5 & 5 & 5 & 5 \\
\hline Total Premium ( in mn Pesos) & 22.962 & 26.317 & 29.192 & 31.899 & 33.397 \\
\hline
\end{tabular}

Source: SSN-GEE Evolution of the Insurance Market Circular No. 2622 dated 11/08/2010

7. Competition has increased on the Argentina insurance market in recent years. In the primary business line for insurance companies in Argentina, motor insurance, risk based premiums are needed. A motor third party liability insurance (MTPL) product is mandatory in Argentina, without Guarantee Fund ${ }^{1}$, and as a result, the dominant activity still remains motor insurance. However, premiums rates and insurance provisions do not properly reflect the underlying risks as they are not based on the underlying risk characteristics and statistical data. Due to high levels of competition, along with a weak prudential supervision combined with the lack of claim data, premium rates are

\footnotetext{
${ }^{1}$ In order to ensure that accident victims are always compensated, guarantee funds should established. These funds regularly receive a portion of each premium paid for MTPL insurance in the country. The funds are placed in trust, to be used excluisevly for the purpose of compensating accident victims.
} 
low and do not cover expected costs. Given the weight of Motor and MTPL businesses in Argentina, SSN should consider issuing a resolution to move to risk based premium on the entire insurance sector starting with Motor and MTPL, and ensuring the adequacy of premium rates guaranteeing the solvency of the insurance industry in the long run.Such resolution can assume two major forms. A common approach is to regulate the size of changes in premium rates; another is to restrict significantly the type of information that can be used to classify risk. The first form of resolution governs changes in the premium growth rates over time; the second affects the magnitude of differences in rates across buyers within a given time period. ${ }^{2}$

Chart 6: Premium Market, 2009

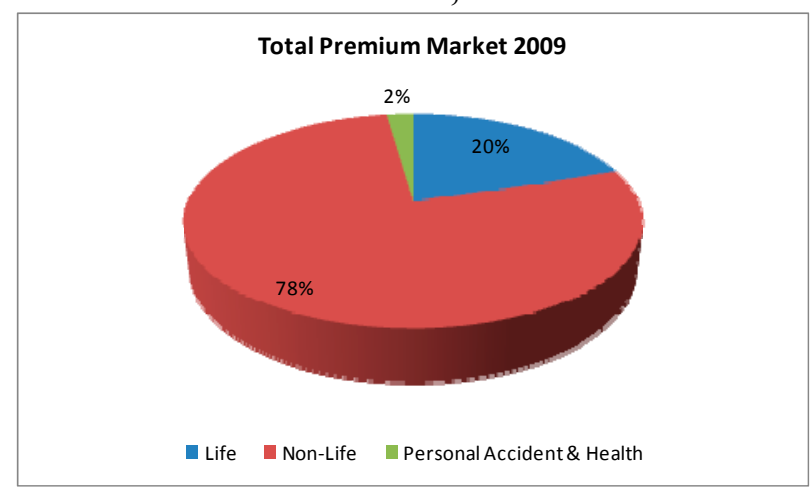

\section{Chart 7: Breakdown of Non-Life premiums}

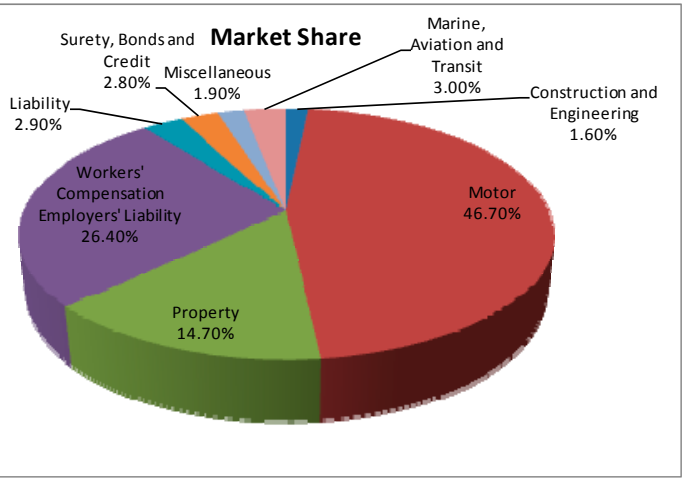

Source: SSN

7. Currently, excessive premium discounting by insurance companies (particularly in MTPL) is creating risks that insurance companies may be under-reserved and may not able to meet future liabilities The financial conditions of insurance companies should be reviewed to properly assess these risks. Many small size insurers are suspected of being under-reserved. Under-reserving is probably frequent among companies specializing in motor insurance because of their adoption of risky rebate policies. This results from low underwriting skills among many direct underwriters as well as from fierce competition. ${ }^{3}$

8. The evolution of liability insurance ${ }^{4}$ in Argentina is positive but will require developing specific expertise. The non-life business in Argentina is dominated by motor, property and other

${ }^{2}$ Economist genaraly agree that the case for requiring prior approval of changes in insurance rates is very weak. When a market liberalizes, new players can enter, which reduces the excessive profits that can be earned as a result of monopoly power. When insurance markets are competitive, lowering overall rates through price regulation is ultimately self defeating. Only competition among players will achieve sustainable lower prices, decreasing the core risk and the loadings on premium.

${ }^{3}$ In some jurisdictions insurance premiums have become insupportably low in MTPL insurance, so that even when combined with investment income there is no sufficient revenue to pay claims and cover expenses, leading to insurance company insolvencies. This phenomenon of untenably low premiums can occur when there is no industry pooling of rating and claims statistics, so that individual insurers, unless they are very large, do not have credible data which can be used for premium setting purposes. High rates of inflation can also lead to premiums being insufficient to cover claims because premium rates are based on the claim experience of prior periods, but are applicable to future periods.

${ }^{4}$ Liability insurance, unlike property insurance which targets damage sustained by specific physical assets (vehicles and fixed structures), covers the financial consequences arising out of the insured's obligation to pay compensation 
liability lines, which together account for more than 90 percent of non-life premiums. On the one hand, the liability-related legal regime is still at a nascent stage, but, if properly nurtured, could imply significant business opportunities for the insurance sector. On the other hand, insurers are being challenged with the need to increase their expertise, foster knowhow, and design products according to market needs, while adequately incorporating legal and market developments into pricing and reserves so as to be able to profitably satisfy growing demand for compensation. The biggest challenge SSN face is thus to find an equilibrium providing fair compensation for victims while keeping the cost of the overall syatem within manageable limits in the years to come. For insurers, these lines of business require a more profound knowledge of local market developments than other lines and an understanding of how they impact the liability regimes, as well as an abilty to manage their exposure appropriately through careful product designs and prudent pricing.

9. Bancassurance ${ }^{5}$ has become an established channel for life insurance distribution in Argentina. Banks currently account for as much as 15 percent of new premiums, which is very impressive considering that most bancassurance regimes are still not fully mature. Specific products are developed for sale through the banks and different sales models exist. All are highly commoditized, relatively inflexible, narrow cover and low cost policies. The banks may have their own sales staff or operate with a mixture of their own and insurance company staff in their branches; insurance staff may be employed full-time in the branches or only part-time, splitting their working days among several offices, especially in the interior; banks are also heavily engaged in selling insurance by telephone and internet; and banks may work with one or several insurers. In order to handle the insurance business, banks must have a registered broker, representatives from which are generally situated in the bank. The banks are said to offer poor claims service.

\section{Insurance regulation and supervision}

10. Despite the fact that insurance has a long history in Argentina, the insurance regulatory agency, in its current form, is in fact relatively new after being restructured in 1973. Insurance Law No: 20.091 and dated 1973 regulated the creation and operation of insurance and reinsurance companies and established minimum capital requirements and technical reserves, as well as specifying the SSN's supervisory duties. Thereafter, noteworthy developments have included the liquidation of the monopoly reinsurance institute (Instituto Nacional de Reaseguros, INder) and the introduction of revised minimum capital requirements for new and existing companies in 1998 and 2006. Currently, the Superintendence of Insurance (Superintendencia de Seguros de la Nación, SSN), which was set up in 1938 and is a part of MECON, has announced

for harm caused to third parties. It is a prime example of so called "long tail" business, where the claims picture will only be fully developed long after the policy has expired. The legal system plays an instrumental role in shaping the evolution of liability insurance.

${ }^{5}$ Bancassurance refers generally to the provision of insurance services by banks. In sigma, bancassurance is defined as "a strategy adopted by banks or insurance companies aiming to operate in the financial market in a more or less integrated manner. This definition highlights the inter-linkages between different financial services, as well as the distribution of these products. Other definitions emphasise the degree of integration between banking and insurance as some observers argue that true bancassurance requires a fairly high degree of integration between two sectors. Other more stringent definitions state that the insurance products must be specifically designed for distribution through bancassurance channels. 
plans to make further changes to its organization, strengthening certain aspects of control by the creation of new departments covering areas such as money laundering and consumer protection. Due attention is also expected to be paid to information technology and insurance company liquidation.

11. In line with developments around the world, the adoption of a risk-based supervisory approach is essential for SSN to properly monitor a rapidly evolving market. The recent growth and sophistication of the sector makes moving towards a framework of more risk-based approach to supervision incorporating risk based capital requirements and strong licensing criteria, necessary. ${ }^{6}$ Such a move should be accompanied by a strengthening of the SSN early warning system 7 and preventive remedial and corrective action framework so as to enable the SSN to react earlier to risks and problems in insurance companies. The move, which should be done in consultation with the industry, will also require capacity building efforts both in the insurance sector and for staff of the SSN. These key elements must be in place, if Argentina is to have world-class regulatory and supervisory system for insurance.

12. SSN has been actively focusing on addressing these challenges. Indeed, SSN plans to move in the direction of a modern model of risk-based regulation and supervision, built around three pillars: i) solvency (through the use of risk-based capital and risk-based supervision), licensing (with a focus on corporate governance), and consumer protection. Regarding licensing, there has been a marked deceleration in new licenses (insurer, branch and sub branch) and specialist insurers (agriculture, health, credit, liability, etc) have been encouraged. Issues of corporate governance and transparency are planned to be tackled in the short term. SSN's plan to move towards a risk-based supervision, upgrade its supporting IT (SINENUP) system, and increase staff salaries in line with those paid by the BCRA, are welcome developments in this regard. The SSN has also developed plans to make changes to its organization, strengthening certain aspects of control though the creation of new departments. Training for supervisory staff is also planned.

13. In addition, while so far the supervision of the insurance market has been instrumental in ensuring market stability, there is a need to further strengthen supervision. The SSN is working on introducing stronger capital requirements and effective "policyholder protection" mechanisms. And the laws 20.091 and 22.400 provide some tools for supervision but should be reviewed and upgraded. While this underlines the firm intention of the authorities to improve the quality and effectiveness of insurance supervision, more efforts are needed to implement a transparent, consultative, more risk-based, and accountable supervision process. In establishing such process, it will be important to consult the industry during the preparatory stages of the main regulations. Also the process should establish an institutional appeal process to enable insurers to contest the findings of on-site supervisors. As importantly, it will be essential to provide safeguards to protect the political and financial independence of the supervisor.

14. To successfully address these challenges, the SSN will need additional resources as well as operational independence to have the ability to offer more competitive salaries to attract and retain qualified staff. While the SSN benefits from a solid endowment in devoted qualified

\footnotetext{
${ }^{6}$ The IAIS has incorporated Risk Based Supervision (RBS) and Risk Based Capital (RBC) approaches into its recognized best practice (and now in its generally accepted good practice) for supervision standards in the insurance sector.

7 The early warning tests provides a "warning flag" to the supervisor, it is important to stress that they are a supplement to, rather than a replacement for, other forms of financial monitoring and tracking.
} 
staff with strong experience in insurance regulation and supervision, its capacity to retain its most talented staff and to recruit staff with market experience is constrained by uncompetitive salaries and insufficient resources.

\section{Summary ASSESSMENT}

Table 1-: Implementation of IAIS Principles

\begin{tabular}{|c|c|c|}
\hline FSAP 2011 Insurance Core Principle & Assessment & Comments \\
\hline $\begin{array}{l}\text { ICP1 - Conditions for effective } \\
\text { insurance supervision }\end{array}$ & $\mathrm{LO}$ & $\begin{array}{l}\text { Review of current supervisory approach as well as its impact } \\
\text { on the insurance industry (for the insurance companies with } \\
\text { different sizes). }\end{array}$ \\
\hline ICP2 - Supervisory objectives & $\mathrm{LO}$ & $\begin{array}{l}\text { Clearly and explicitly define supervisory objectives and report } \\
\text { on progress toward their achievement. SSN's strategic and } \\
\text { business plans for insurance regulation and supervision should } \\
\text { be developed. }\end{array}$ \\
\hline ICP3 - Supervisory authority & PO & $\begin{array}{l}\text { The supervision department needs to increase its capacity to } \\
\text { achieve effective supervision. } \\
\text { The institutional set of insurance supervision and regulations } \\
\text { requires changes to ensure the SSN's political, operational, and } \\
\text { financial independence, including its control on changes in HR } \\
\text { and training policies, investment in IT infrastructure and } \\
\text { regulatory tools needed. Improvement is required in legal } \\
\text { protections for SSN supervisors. Improvement is required in } \\
\text { legal protections for SSN staff. }\end{array}$ \\
\hline ICP4 - Supervisory process & $\mathrm{PO}$ & $\begin{array}{l}\text { There is no clearly established regulatory process that would be } \\
\text { open to the public and provide for adequate technical } \\
\text { consultations with the insurance industry. To be compliant the } \\
\text { supervisor needs to undertake major changes in the way it } \\
\text { currently operates. The introduction of more risk based } \\
\text { supervision along with risk based capital should be considered. } \\
\text { Carry out expert review of current early warning system and } \\
\text { enact best-practise for it. The supervisor should consider } \\
\text { carrying out impact assessment studies before enacting any } \\
\text { regulations that may adversely affect the economics of the } \\
\text { industry. }\end{array}$ \\
\hline $\begin{array}{l}\text { ICP5 - Supervisory cooperation and } \\
\text { information sharing }\end{array}$ & $\mathrm{LO}$ & $\begin{array}{l}\text { Consider developing specific protocols on day-to-day } \\
\text { information sharing with other relevant financial sector } \\
\text { supervisors. }\end{array}$ \\
\hline ICP6 - Licensing & PO & $\begin{array}{l}\text { Require comprehensive business plans and obtain input from } \\
\text { foreign supervisors as additional proof of compliance on some } \\
\text { key licensing criteria. }\end{array}$ \\
\hline ICP7 - Suitability of persons & $\mathrm{PO}$ & There is room for improvement (see detailed assessment). \\
\hline $\begin{array}{l}\text { ICP8 - Changes in control and portfolio } \\
\text { transfers }\end{array}$ & $\mathrm{LO}$ & $\begin{array}{l}\text { Guidelines should be issued outlining the processes to be } \\
\text { followed in case of application for approval of a portfolio } \\
\text { transfer. }\end{array}$ \\
\hline ICP9-Corporate governance & $\mathrm{PO}$ & Corporate governance requires strengthening. \\
\hline
\end{tabular}




\begin{tabular}{|c|c|c|}
\hline ICP10 - Internal controls & PO & $\begin{array}{l}\text { A review and Guidelines along with Corporate Governance } \\
\text { would be very helpful to implement practices that will improve } \\
\text { compliance with expectations in the area of monitoring internal } \\
\text { controls. }\end{array}$ \\
\hline ICP11 - Market analysis & $\mathrm{PO}$ & $\begin{array}{l}\text { Data collected for analysis appear to be excessive; consider } \\
\text { delegating all market data collection and publication } \\
\text { responsibilities to the Association of Insurance and } \\
\text { Reinsurance Companies. The market analysis should not only } \\
\text { include past developments and the present situation, but also } \\
\text { aim to identify trends and possible future scenarios and issues, } \\
\text { so that the supervisory authority is well prepared to take action } \\
\text { at an early stage, if required }\end{array}$ \\
\hline $\begin{array}{l}\text { ICP12 - Reporting to supervisors and } \\
\text { off-site monitoring }\end{array}$ & PO & $\begin{array}{l}\text { Early warning tools should be upgraded. Data collection and } \\
\text { analysis should be enhanced to support risk-based and group- } \\
\text { wide supervision. }\end{array}$ \\
\hline ICP13 - On-site inspection & LO & $\begin{array}{l}\text { The government should allocate sufficient resources for the } \\
\text { upgrading of the insurance supervision. }\end{array}$ \\
\hline $\begin{array}{l}\text { ICP14 - Preventive and corrective } \\
\text { measures }\end{array}$ & $\mathrm{PO}$ & $\begin{array}{l}\text { There is a need for a ladder of intervention and the legal } \\
\text { powers to enforce it }\end{array}$ \\
\hline ICP15 - Enforcement or sanctions & LO & $\begin{array}{l}\text { SSN should have full power to take control of the insurer, or } \\
\text { appoint other specified officials or receivers for the task, and } \\
\text { make such arrangements for the benefit of the policyholders as } \\
\text { deemed necessary }\end{array}$ \\
\hline $\begin{array}{l}\text { ICP16 - Winding-up or exit from the } \\
\text { market }\end{array}$ & LO & $\begin{array}{l}\text { The basic general framework does not provide for a guarantee } \\
\text { fund in the case of a company's insolvency, except to cover the } \\
\text { benefits that an insurer against work-related risks fails to } \\
\text { deliver because of its liquidation }\end{array}$ \\
\hline ICP17 - Group-wide supervision & NO & $\begin{array}{l}\text { As a first step, legislation should enable SSN to request } \\
\text { whatever information is required. In addition, SSN should } \\
\text { implement the following measures to facilitate group } \\
\text { supervision: } \\
\text { - undertake solvency calculation on a group wide basis } \\
\text { for all insurance groups } \\
\text { - provide a clear definition of an insurance group so } \\
\text { that the SSN and insurers can determine: which } \\
\text { groups are considered to be insurance groups or } \\
\text { financial conglormerates, as well as the scope of the } \\
\text { supervision } \\
\text { define an approach to calculate group financial } \\
\text { conditions } \\
\text { prescribe the remedial action that can be taken against } \\
\text { solo entity that should also be available in respect to } \\
\text { an insurance group. }\end{array}$ \\
\hline $\begin{array}{l}\text { ICP18 - Risk assessment and } \\
\text { management }\end{array}$ & $\mathrm{PO}$ & $\begin{array}{l}\text { Introduce more risk-based supervisory approach and reflect it } \\
\text { in on-site inspection manuals. Distinguish between small and } \\
\text { large size companies in terms of risk management } \\
\text { requirements to make the compliance with the regulations } \\
\text { feasible for smaller market players. }\end{array}$ \\
\hline ICP19 - Insurance activity & $\mathrm{PO}$ & $\begin{array}{l}\text { Develop and introduce detailed inspection manuals and } \\
\text { regulatory tools that can guide the supervisor's analysis of } \\
\text { companies' net risk retention/reinsurance policies for portfolios } \\
\text { of insurance risk. }\end{array}$ \\
\hline
\end{tabular}




\begin{tabular}{|l|l|l|}
\hline ICP20 - Liabilities & LO & $\begin{array}{l}\text { Update reserving methods required of the industry to avoid } \\
\text { under-reserving, particularly in liability insurance. }\end{array}$ \\
\hline ICP21 - Investments & LO & NA \\
\hline $\begin{array}{l}\text { ICP22 - Derivatives and similar } \\
\text { commitments }\end{array}$ & PO & $\begin{array}{l}\text { Enhatation of investments is required. } \\
\text { based and solvency control requirements, which would enable } \\
\text { the regulator to initiate corrective actions (e.g. require an } \\
\text { additional capital buffer to be restored) before the minimum } \\
\text { solvency threshold has been breached. }\end{array}$ \\
\hline ICP24 - Capital adequacy and solvency & $\begin{array}{l}\text { Automate the monitoring of intermediaries' compliance with } \\
\text { the main licensing requirements by developing a special } \\
\text { computer program that can be run by the SSN on the agents' } \\
\text { compliance reporting database. }\end{array}$ \\
\hline ICP25 - Consumer protection & LO & $\begin{array}{l}\text { SSN should require insurers and intermediaries to seek } \\
\text { information from their consumers that is appropriate in order to } \\
\text { asses their insurance needs, before giving advice or } \\
\text { conculuding a contract. }\end{array}$ \\
\hline $\begin{array}{l}\text { ICP26 - Information, disclosure and } \\
\text { transparency to the market }\end{array}$ & LO & $\begin{array}{l}\text { Develop and publish a set of ratios and data inputs from } \\
\text { insurance companies' reports that would allow market players } \\
\text { and investors to analyze the financial condition of insurers on a } \\
\text { quarterly basis. Store annual information in a database format } \\
\text { to enable the public to create data series and graphs for key } \\
\text { financial parameters/ratios of insurers. }\end{array}$ \\
\hline $\begin{array}{l}\text { ICP28 - Anti-money-laundering, } \\
\text { combating the financing terrorism }\end{array}$ & $\begin{array}{l}\text { The SSN should co-operate with other supervisory authorities } \\
\text { including, as appropriate, in other jurisdictions in countering } \\
\text { fraud. }\end{array}$ \\
\hline
\end{tabular}

Notes: O - Observed; LO - Largely Observed; PO - Partly Observed: NO - Not Observed A Principle is considered observed whenever all the essential criteria are considered to be observed or when all the essential criteria are observed except for a number that are considered not applicable. For a Principle to be considered largely observed, it is necessary that only minor shortcomings exist which do not raise any concerns about the authority's ability to achieve full observance with the Principle. A Principle is considered partly observed whenever, despite progress, the shortcomings are sufficient to raise doubts about the authority's ability to achieve observance. A Principle is considered not observed whenever no substantive progress toward observance has been achieved. 


\section{Table 2. Detailed Assessment of Observance of the Insurance Core Principles}

\begin{tabular}{|ll|}
\hline Conditions for Effective Insurance Supervision \\
\hline Principle 1. & Conditions for effective insurance supervision \\
& Insurance supervision relies upon: \\
& - a policy, institutional and legal framework for financial sector supervision \\
& - a well developed and effective financial market infrastructure \\
& - efficient financial markets.
\end{tabular}

Description

Financial sector policy framework

The government establishes and publicly discloses a policy statement aimed at ensuring financial stability, including the provision of effective financial sector supervision covering insurance and other financial sectors.

The financial crisis at the end of 2001 resulted in the largest economic collapse and loss of public confidence in Argentina's recent history. The market shows a constant increase in non-life insurance, both in the case of compulsory and non-compulsory insurances. This reflects a positive condition of the current market. In 2010 there are signs of recovery in the market, although at a slow pace.

During this period SSN policy was focused on protecting the interests of its consumers (policyholders), strengthening the market, and introducing emergency mechanisms for dealing with the serious crisis.

The government has shown a willingness to develop a stronger supporting regulatory and supervisory framework. This was most clearly manifested by the regulations and resolutions, which strengthened a number of prudential requirements, including increasing minimum capital. The law is structured as an overriding framework and provides considerable scope for regulatory development, largely along prudential lines. However it is constraining in terms of developing a fullly risk based approach, being quite specific and derterministic. The insurance market is still in the development stage in Argentina, sitting between Brazil and Colombia in terms of penetration ratio as a proportion of GDP.

The Argentine Republic has a system of legal provisions that regulate its basic public and private institutions. In the case of the insurance sector, the legislature regulates not only the insurance contracts but also insurance and intermediary activities, and it has granted government-level policing powers in this area to the head of the SSN (Laws 17,418, 20,091, and 22,400).

An institutional and legal framework - comprising public institutions, laws and regulations - exists for financial sector issues, including those pertaining to insurance, to address system-wide issues. This framework is well-defined and publicly disclosed.

Different segments of the financial sector are regulated by agencies/institutions specific to these subsectors There is an extensive and well defined body of sub-sectoral legislation pertaining to insurance, banking, and securities markets. No overarching legislation exists.

There is no comprehensive institutional and regulatory framework for the financial sector that would be able to address system-wide issues. 
Although an MOU was signed recently between SSN and the Central Bank of Argentina (BCRA) and in June, 2011 with the CNV, informal communication is said to be good between the three institutions, the sector-wide cooperation efforts are still in their infancy and implementation of the MOU has not yet begun.

\section{Financial market infrastructure}

There is a reliable, effective, efficient and fair legal and court system (a body of ethical, professional and trained lawyers and judges) whose decisions are enforceable. Alternative dispute mechanisms operate within an appropriate legal framework.

Currently, there are three mechanisms available to the public for the purposes of dispute resolution. Those include (i) arbitration; (ii) government sponsored consumer-protection agency and (iii) civil courts. Consumers can approach the consumer protection agency to address their grievances. Complainants can use all three venues to obtain binding decisions on insurers. However, the courts are rarely used, due to the often rather long delays in achieving resolution. It takes on average of 3-5 years and occasionally much longer for a case to go through the full court procedure.

The administrative system established by General Resolution SSN No. 35.840 dated $06 / 03 / 2011$ within the framework of the defense of consumer rights, contemplates a conciliation stage within the entity. In case it fails, it then gives rise to the involvement of the SSN for an administrative solution. In addition, there are rules that contemplate a mediation instance prior to resorting to the courts. It is customary for the insured to resort to the civil courts to solve conflicts with insurers, as illustrated by the very high litigation rate. This in turn leads toheavy information requirements that the insurers are required to submit to the SSN. In the case of other conflicts which could arise between the insurers and the SSN, prior to the judicial instance, it is necessary to follow the administrative instance regulated by law 19.549, which can produce the resolution of the conflict.

Judges are adequately qualified on issues regarding insurance, with some of them even having an extended academic background, with specialization in insurance from different universities. In addition, judges often refer to antecedent projects that were prepared by members of the Judiciary.

Yet, for disputes between the government and insurance companies, civil courts still remain the only venue available to plaintiffs, a fact which considerably limits the ability of the insurance industry to challenge government regulations or company specific regulatory actions.

Accounting, actuarial and auditing standards are comprehensive, documented, transparent and consistent with international standards. Accounting and actuarial standards are applied and disclosed in a manner that allows current and prospective policyholders, investors, intermediaries, creditors and supervisors to properly evaluate the financial condition of insurers.

Insurers are required to appoint external auditors and have their annual financial statements audited. Both the annual financial statements and the quarterly ones have to be 
submitted with the External Auditor's Report, with signature certified by the corresponding Professional Council of Economic Sciences.

The Argentine Actuarial Institute is a technical organization which develops technical papers that are assessed by the Professional Councils and Universities. The jurisdictional Professional Councils establish technical standards through the Argentine Federation of Professional Councils of Economic Sciences. In effect, all their registered members (accountants, actuaries, business administration graduates, economists) should comply with technical and ethical standards (there is a Code of Ethics for all the professionals) and lack of observance thereof results in the intervention of the Council's "Discipline Tribunals". In Argentina there are Professional Councils and associations of graduates, but it is the councils that by law control registration, the issuance of standards and the application of penalties. The associations of graduates (Actuarial Institute, Graduate Associations) are mostly union-like and/or technical organizations. In some provinces associations have even "merged" with the councils.

Auditors and Actuaries are registered with the SSN; therefore the SSN has the power to impose sanctions on them and could even cancel their registration, in which case they would be unable to work for insurers. Likewise, when a sanction is applied to a registered professional, this is communicated to the respective Professional Councils so that they may also start the corresponding summary proceedings. Both the SSN and the Professional Councils can impose sanctions on the professionals in their registries.

Accounts are currently prepared in accordance with Argentinean GAAP. Foreign companies may apply IAS or their national GAAP but reconciliation to Argentinean GAAP is required. International Financial Reporting Standards (IFRS) will apply to all companies listed on the stock exchange starting on January 2012; the intention is to apply it also to the insurance market but no timetable for such a development has been established. Although insurance companies are not explicitly obliged to present their financial statements in accordance with IFRS. The SSN is aware that at the international level, IFRS are considered to be the standards that will make it possible to homogenize the accounting and financial information of companies at a global level, thus fostering commercial relations, investments and business by providing a framework of understanding regarding financial reports. The SSN is currently analyzing the impact of the implementation of IFRS to later define an action plan to migrate the financial reports of the insurance market towards these standards.

The situation in Argentina regarding IFRS has its precedent in Technical Resolution No. 26 which incorporated the adoption of the IFRS issued by the IASB (International Accounting Standards Board) as accounting standards.

Accountants, actuaries and auditors are competent and experienced and comply with technical and ethical standards to ensure the accuracy and reliability of financial data and its interpretation. Auditors are independent from the insurer.

SSN Resolution 29,053, establishes the requirements to be met by external auditors and actuaries in order to be included in the SSN Registry of External Auditors and Actuaries. This registration qualifies them to provide their services to the supervised insurers. Furthermore, the provision specifies the suitability requirements that need to be met in order for these professionals to qualify for the Registry. 


\begin{tabular}{|c|c|}
\hline & 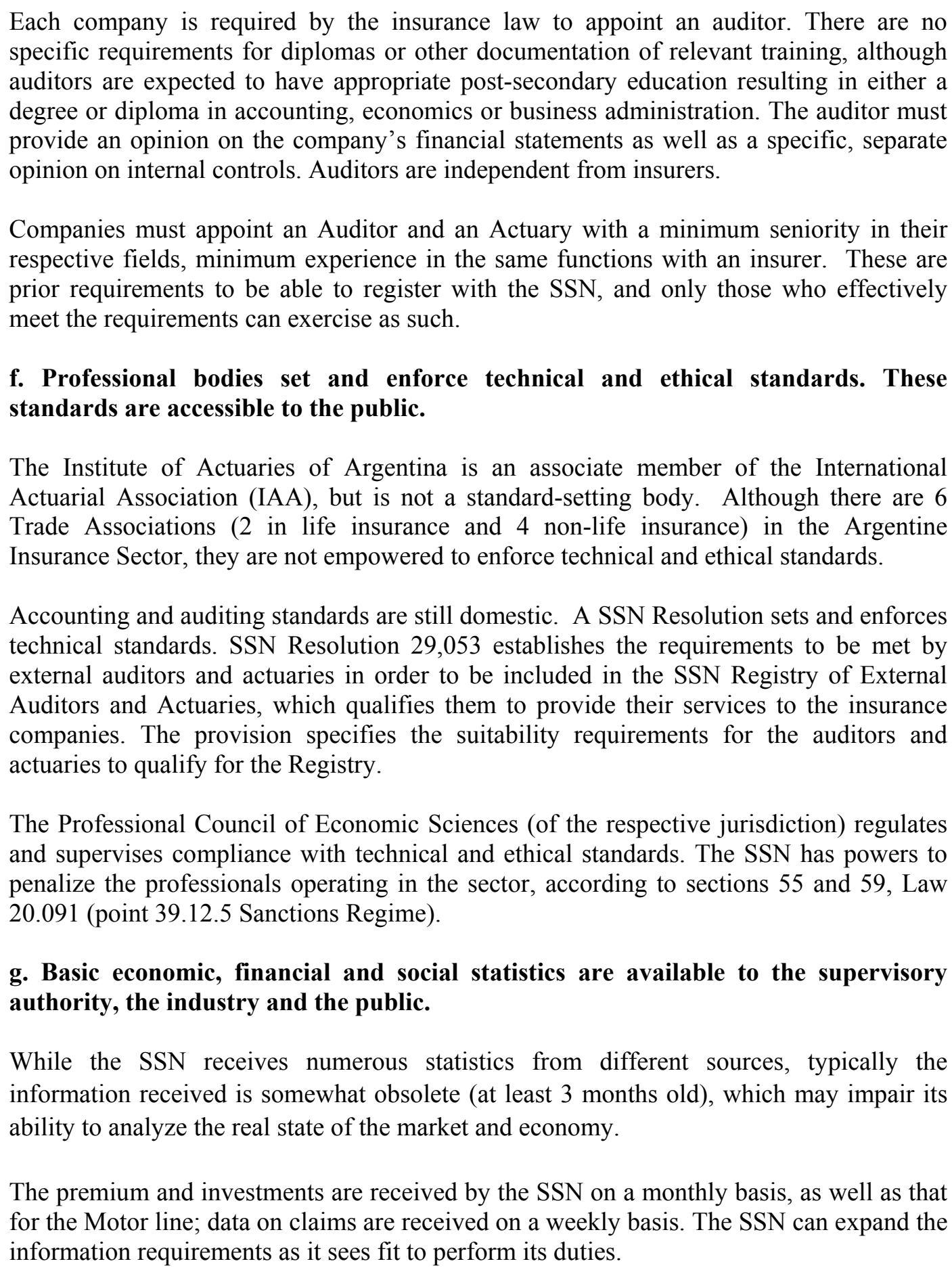 \\
\hline Assessment & $\mathrm{LO}$ \\
\hline Comments & $\begin{array}{l}\text { A review of the current supervisory approach as well as its impact on the insurance } \\
\text { industry would be warranted (for the insurance companies with different sizes). The } \\
\text { introduction of more risk based supervision along with risk based capital should be } \\
\text { considered. Carrying out an expert review of the current early warning system would also } \\
\text { be recommended. }\end{array}$ \\
\hline
\end{tabular}




\begin{abstract}
The Supervisory System
Principle 2. Supervisory objectives

The principal objectives of insurance supervision are clearly defined.

\begin{tabular}{|l|l} 
Description & Legislation or regulation clearly defines the objectives of insurance supervision.
\end{tabular}

The National Insurance Superintendency (SSN) is a decentralized public agency under the MECON. Its primary mandate is to supervise all insurers, for which purpose it inspects the organization, operation, solvency, and liquidation of insurers, as well as the activities of reinsurers and intermediaries and advisors at both levels.

The scope of the insurance supervision is regulated in the Insurance Act (IA) 20,091 covering the activity of insurance and reinsurance companies, the branches and offices of representatives of foreign insurance companies, as well as the activities of the various bodies that are related to the insurance industry (insurance brokers and advisors, proxy agents, auditors, actuaries and experts and liquidators of damages).

The SSN has been given the mandate to supervise insurance and reinsurance companies in the Argentina Republic in order to ensure a solvent, stable, and efficient market, thus helping to guarantee the protection of citizen consumers, in keeping with the principles of Law 20,091.

The regulations governing the insurance sector clearly define the objectives of supervision. National Executive Decree 1,084/2004 stipulates that the main objective shall be to exercise comprehensive supervision over the insurance and reinsurance market in the Argentine Republic with a view to promoting a solvent, stable, and efficient market. On certain occasions, the SSN publishes guidelines to explain how a given objective is applied, or to clarify the legal basis for the administrative actions taken by SSN in the exercise of its duties.
\end{abstract}

The key objectives of supervision promote the maintenance of efficient, fair, safe and stable insurance markets for the benefit and protection of policyholders.

The maintenance of efficient, fair, safe and stable insurance market for the benefit and protection of policyholders is required by the IA.

The supervisory authority gives reasons for and explains any deviations from its objectives.

Within the framework of formulating the Agency's Annual Budget, the SSN establishes supervisory targets, as background for an instrument that the National Executive sends to the National Congress to pass the Annual Budget Law. Likewise, the Annual Report reflects the extent to which the objectives have been met and accounts for any deviations.

Where objectives are contradictory, the supervisory authority initiates or proposes correction in law or regulation.

While SSN asks the industry to comment on new draft regulations, the process is not well defined and often not followed through. Often insurers are asked for inputs only a few days before the drafts are finalized and sometimes not asked at all. There is no mechanism to ensure that industry's comments are taken into consideration. Some regulations appear to have been enacted completely at odds with the views of the industry. 


\begin{tabular}{|c|c|}
\hline & $\begin{array}{l}\text { SSN has powers as regulator to issue regulations, notwithstanding the fact that it advises } \\
\text { the National Executive on matters related to insurance, so that it makes valuable } \\
\text { contributions to the draft bills that would-eventually-be designed to correct or harmonize } \\
\text { better the regulations in force. }\end{array}$ \\
\hline Assessment & LO \\
\hline Comments & $\begin{array}{l}\text { The SSN has a clear mission on its supervisory objectives and publishes statements of its } \\
\text { mission. These set out clearly the appropriate objectives in this respect. The SSN has a } \\
\text { "Strategic Training Plan" which sets training targets, objectives and action plans for a } \\
\text { certain period of time. However the SSN has no business plans on insurance, nor a } \\
\text { mechanism to deliver its objectives, but it publishes an annual report giving their } \\
\text { standpoint on the performance. } \\
\text { Supervisory targets, progress toward fulfilling the objectives and deviation from the } \\
\text { targets are neither monitored nor disclosed. } \\
\text { The SSN's strategic and business plans for insurance regulation and supervision should } \\
\text { be developed. }\end{array}$ \\
\hline Principle 3. & $\begin{array}{l}\text { Supervisory authority } \\
\text { The supervisory authority: } \\
\text { - has adequate powers, legal protection and financial resources to exercise its } \\
\text { functions and powers } \\
\text { - is operationally independent and accountable in the exercise of its functions and } \\
\text { powers } \\
\text { - hires, trains and maintains sufficient staff with high professional standards } \\
\text { - treats confidential information appropriately. }\end{array}$ \\
\hline Description & $\begin{array}{l}\text { Legal Framework } \\
\text { The legislation identifies the authority (or authorities) responsible for the supervision } \\
\text { of insurance entities. } \\
\text { Article } 28 \text { of the Insurance Law on the creation of National Insurance } \\
\text { Superintendence (Superintendencia de Seguros de la Nación)- SSN dates from } 1937 \\
\text { (Decree 108,295), describes the institutions mission as "to regulate and supervise the } \\
\text { insurance sector", an area of activity that has been gaining importance since its first } \\
\text { operations got under way at the end of the eighteenth century. } \\
\text { The SSN is, according to the Act } 20,091 \text { "the competent authority for the supervision on } \\
\text { of insurance sector", being a regulator and supervisor for insurance and reinsurance } \\
\text { companies, intermediaries and claims adjusters. } \\
\text { The governance structure is well defined with a Superintendent, one Deputy and eight } \\
\text { department heads. The Superintendent is assisted by an Advisory Board consisting of } 5 \\
\text { insurance directors appointed by the President (Law 20091-Article 76-80). The } \\
\text { superintendence comprises eight divisions ranging from the legal to the technical and } \\
\text { from inspection to statistics. In addition, the internal audit unit is responsible for checking } \\
\text { the SSN's own accounts and systems in accordance with the provisions of Law No } 24.156 . \\
\text { The head of the SSN bears the title "Superintendent of Insurance" and is assisted by the } \\
\text { "Vice Superintendent." Both are appointed and removed by the President. Appointment is } \\
\text { not for a fixed term. Reasons for removal of Superintendent, vice superintendent and }\end{array}$ \\
\hline
\end{tabular}


department heads are not publically disclosed

Independence and Accountability

The SSN reports to the National General Treasury, the agency responsible for the management of public funds, which coordinates operation of the Unified Account in all the jurisdictional treasuries of the Financial Administrative Services (SAFs) operating in the National Public Sector (Law 24,156, Article 74 Law on the Unified Account System, and National Executive Decrees 1,545/1994 and 2,360/1994).

The SSN has discretion to allocate its resources in accordance to its approved Budget. Governance of SSN includes an internal audit process. While budget is approved by the Minister of Finance and production, SSN prepares its own budget but it is subject to an agreement process.

\section{Powers}

The legal framework provides well defined monitoring and enforcement authority to the SSN and SSN has full power to issue regulations and resolutions. The powers of the SSN are generally adequate for supervision. At present, the SSN can exercise these powers only in case of non-compliance with specific rules in the legislation. The SSN has no authority to arrange the compulsory transfer of the obligations under policies from a failing insurer to another insurer that accepts this transfer.

Experience has shown that the SSN may not use its power to intervene in a troubled company until certain circumstances are demonstrated - at which time it could be too late for remedial action.

\section{Financial resources:}

In Argentina the companies do contribute to the cost of supervision, but the funds are collected by the Ministry of Finance, which provides the budget to SSN. SSN has discretion to allocate its resources in accordance with its approved budget, and sets its own spending plans.

Salaries of SSN staff are not benchmarked to market rates and are much lower (50 percent) than those of the Central Bank of Argentina. This discrepancy and the lack of full independence with regard to the remuneration negatively affect the ability to recruit and retain highly qualified staff. SSN can hire external consultants if needed, and provide training to its own staff.

SSN employees appear to have an appropriate level of skill and experience. Particular effort should be paid to retain these qualities while maintaining high standards of integrity and compliance with specific norms related to ethics and probity in relevance to their public position.

\section{Legal protection and Confidentiality:}

SSN staff are civil servants and subject to civil service protections and confidentiality requirements. In addition, Art. 74 of the Law 20.091 specifically require that SSN staff and officers observe confidentiality of commercial and other legal secrets. There does not appear to be any measure of legal protection for other staff members. 


\begin{tabular}{|c|c|}
\hline & $\begin{array}{l}\text { The assessors did not receive evidence that any internal procedures or the employee- } \\
\text { employer agreement require the SSN to finance the legal defense of individual officials } \\
\text { and staff in case they are personally sued for acts or omissions committed in the exercise } \\
\text { of their official responsibilities in good faith. Although there have not been any law suits } \\
\text { against its employees, SSN considers that its legal department would be instrumental in } \\
\text { preparing the defense and providing expertise on the financial-legal aspects of the case. In } \\
\text { such cases, the supervisor's individual officials and staff members should be represented } \\
\text { in court by a legal counsel from SSN. }\end{array}$ \\
\hline Assessment & $\mathrm{LO}$ \\
\hline Comments & $\begin{array}{l}\text { To support the independence and integrity of the SSN, there should be provisions for the } \\
\text { legal protection of staff, as well as clear rules for appointment and removal of the } \\
\text { Superintendent. When the Superintendent is removed from office, the reasons should be } \\
\text { publicly disclosed. The appointment of the Superintendent should be for a fixed term. } \\
\text { The SSN has powers to impose different precautionary measures; these are regulated in } \\
\text { accordance with the seriousness of the emerging issue (pursuant to Sections } 31 \text { and } 86 \text { of } \\
\text { Law } 20.091 \text {-text of Law } 24.241-\text { ) including, in exceptional and serious situations, the } \\
\text { possibility of asking for a judicial intervention of the insurer. } \\
\text { The supervision department needs to increase its capacity to achieve effective supervision } \\
\text { (through risk based capital ) } \\
\text { More legal clarity is needed regarding the protection against liabilities resulting from } \\
\text { actions or omissions when discharging their duties in good faith of all the members of the } \\
\text { SSN. The legal framework should specifically state that the legal protection to SSN } \\
\text { employees extends beyond their termination of employment or appointment and that SSN } \\
\text { is held responsible for covering eventual legal defense costs. }\end{array}$ \\
\hline Princ & $\begin{array}{l}\text { Supervisory process } \\
\text { The supervisory authority conducts its functions in a transparent and accountable manner. }\end{array}$ \\
\hline Description & $\begin{array}{l}\text { The supervisory authority adopts clear, transparent and consistent regulatory and } \\
\text { supervisory processes. The rules and procedures of the supervisory authority are } \\
\text { published and updated regularly. } \\
\text { The scope of the inspection is defined prior to the beginning of an inspection. Likewise, } \\
\text { once an inspection has been completed, the results and conclusions of the same are } \\
\text { presented in a File with the involvement of the Evaluation Department and the Legal } \\
\text { Department (and sometimes the Technical Department, as may be the case) validating } \\
\text { their involvement from the point of view of their responsibilities. Besides, during the } \\
\text { inspections there is a fluid interaction with those in charge of the Insurers and, in case it is } \\
\text { necessary, with the senior management of the same. } \\
\text { There is no clearly defined process for preparing and enacting regulations; draft } \\
\text { regulations are not always made available to the insurance industry or provided on a short } \\
\text { notice. The information required from an inspected company is announced only a few } \\
\text { days in advance. } \\
\text { The supervisory authority applies all regulations and administrative procedures } \\
\text { consistently and equitably, taking into account the different risk profiles of insurers. }\end{array}$ \\
\hline
\end{tabular}


Although the supervisor applies all regulations consistently and equitably, no distinction is made by SSN between small and large insurers - the same compliance requirements apply, which results in undue high regulatory compliance burden for smaller and mid-size companies.

The technical and legal system is not based on a prudential supervision adjusted for risk exposure (for example, Solvency II). The adoption of measures is underway to adopt such a model, with, for example, rules requiring insurers to credit positive technical results, or imposing different regimes regarding the internal control of insurers and the management of their investment portfolios. On the other hand, the solvency requirements to be met by insurers (especially with regard to minimum capital) are measured largely based on volumes.

\section{The supervisory authority makes information on its role publicly available.}

SSN makes available all its regulatory requirements and primary legislation on its website, updating the material as changes take effect and all are accessible directly or via links on the SSN website. The office produces an annual report in Spanish and maintains a comprehensive web site that also updates industry flow data (premiums and claims), analyzed by company and region, on a quarterly basis.

The decision-making lines of the supervisory authority are so structured that action can be taken immediately in the case of an emergency situation (refer to ICP 3 EC n and ICP 15).

The decision-making line of the SSN is well structured and effective. All critical decisions in the end must be taken by the Superintendent. Therefore there are no delays between the time the company breaches a minimum required solvency threshold and the moment when its ability to write new business is revoked along with the license.

The process to appeal supervisory decisions is specified and balanced to preserve supervisory independence and effectiveness.

The IA establishes that "The official to whom the inspection of an insurer or the control of its balance sheet is entrusted will produce a written report. In case it results in observations from the Superintendence, the Agency will provide the insurer with the items of the inspection on which it is founded." In that sense, the supervision of the entities does not imply an inquisitorial process but rather a completely transparent one. But in any case, any decisions that are eventually adopted as a result of the inspections or any other information collected are materialized in observance of the rules of procedure specifically established in section 82 of the law of reference, which also establishes a judicial review procedure of said decisions, pursuant to section 83 of the law.

The supervisory authority publishes a regular report - at least annually and in a timely manner - on the conduct of its policy, explaining its objectives and describing its performance in pursuing its objectives.

The SSN publish the Strategic Training Plan and the Agency's Annual Report. 


\begin{tabular}{|c|c|}
\hline Assessment & $\mathrm{PO}$ \\
\hline Comments & $\begin{array}{l}\text { The supervisory authority needs to fundamentally change the way it develops and enacts } \\
\text { insurance regulations. There must be a statutory process that would provide the industry } \\
\text { the opportunity to comment on draft and final draft regulations. The supervisor should } \\
\text { consider carrying out impact assessment studies before enacting any regulations that may } \\
\text { adversely affect the economics of the industry. } \\
\text { SSN should publish an annual report on the conduct of its policy, explaining its objectives } \\
\text { and describing its performance in pursuing its objectives. }\end{array}$ \\
\hline Principle 5. & $\begin{array}{l}\text { Supervisory cooperation and information sharing } \\
\text { The supervisory authority cooperates and shares information with other relevant } \\
\text { supervisors subject to confidentiality requirements. }\end{array}$ \\
\hline Description & $\begin{array}{l}\text { Recently the SSN signed a MOU with BCRA and CNV to exchange information and to } \\
\text { work together. } \\
\text { At present there is no restriction on the SSN sharing information with the other financial } \\
\text { regulatory authorities if it does not constitute a state secret. And no formal agreement is } \\
\text { required by SSN before exchanging information with another authority. There are no } \\
\text { existing obligations to share information on a home - host basis relating to actions that } \\
\text { may be relevant to the other supervisor. In Argentina a strict reciprocity is a requirement } \\
\text { for the exchange of information with the host supervisor. And the SSN takes steps to } \\
\text { ensure both confidentiality and supervisory processes are in place. } \\
\text { Within the context of Mercosur, the SSN is a signatory to the Mercosur cooperation } \\
\text { agreement (Mercosur/CMC/Dec. } 8 / 99 \text { ) under which it is committed to provide, insofar as } \\
\text { possible, all information requested by any of the other States Party on all significant } \\
\text { aspects that might affect the solvency and stability of insurance companies subject to } \\
\text { supervision. And as a member of ASSAL and through its contacts with insurance } \\
\text { supervisors in other countries, SSN has on occasion exchanged information concerning } \\
\text { certain companies. } \\
\text { Although an MOU was signed recently between the SSN and the Central Bank of } \\
\text { Argentina (BCRA) and on June, } 2011 \text { with the CNV, and informal communication is said } \\
\text { to be good between the three institutions, sector-wide cooperation efforts are still in their } \\
\text { infancy and implementation of the MOU has not yet begun. } \\
\text { Also, if necessary, the SSN has authority to exchange information of the nature indicated } \\
\text { above with supervisors in other states. } \\
\text { SSN is a member of IAIS. }\end{array}$ \\
\hline Assessment & $\mathrm{LO}$ \\
\hline Comments & $\begin{array}{l}\text { When reasonably requested and with appropriate safeguards, the SSN should be able to } \\
\text { exchange with another supervisor the following: } \\
\text { - Relevant supervisory information, including specific information requested and } \\
\text { gathered from a supervised entity } \\
\text { - Relevant financial data } \\
\text { - Objective information on individuals holding positions of responsibility in } \\
\text { insurance and reinsurance companies. } \\
\text { Information sharing, whether carried out under formal or informal arrangements, allows }\end{array}$ \\
\hline
\end{tabular}




\begin{tabular}{|c|c|}
\hline & $\begin{array}{l}\text { for a two-way flow of information without strict reciprocity in terms of the level, format } \\
\text { and detailed characteristics of the information exchanged. }\end{array}$ \\
\hline \multicolumn{2}{|c|}{ The Supervised Entity } \\
\hline Principle 6. & $\begin{array}{l}\text { Licensing } \\
\text { An insurer must be licensed before it can operate within a jurisdiction. The } \\
\text { requirements for licensing are clear, objective and public. }\end{array}$ \\
\hline Description & 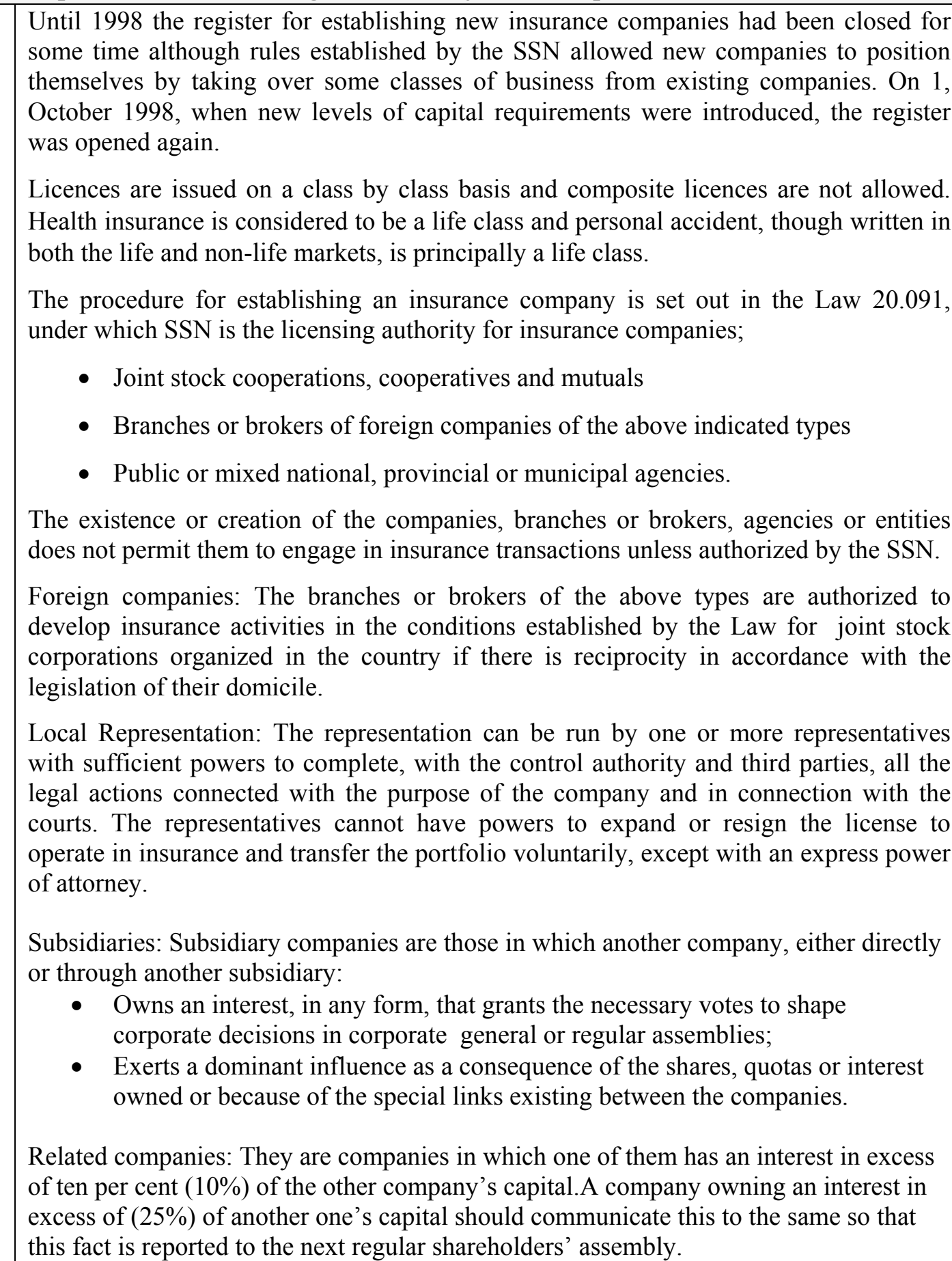 \\
\hline
\end{tabular}




\begin{tabular}{|c|c|}
\hline & 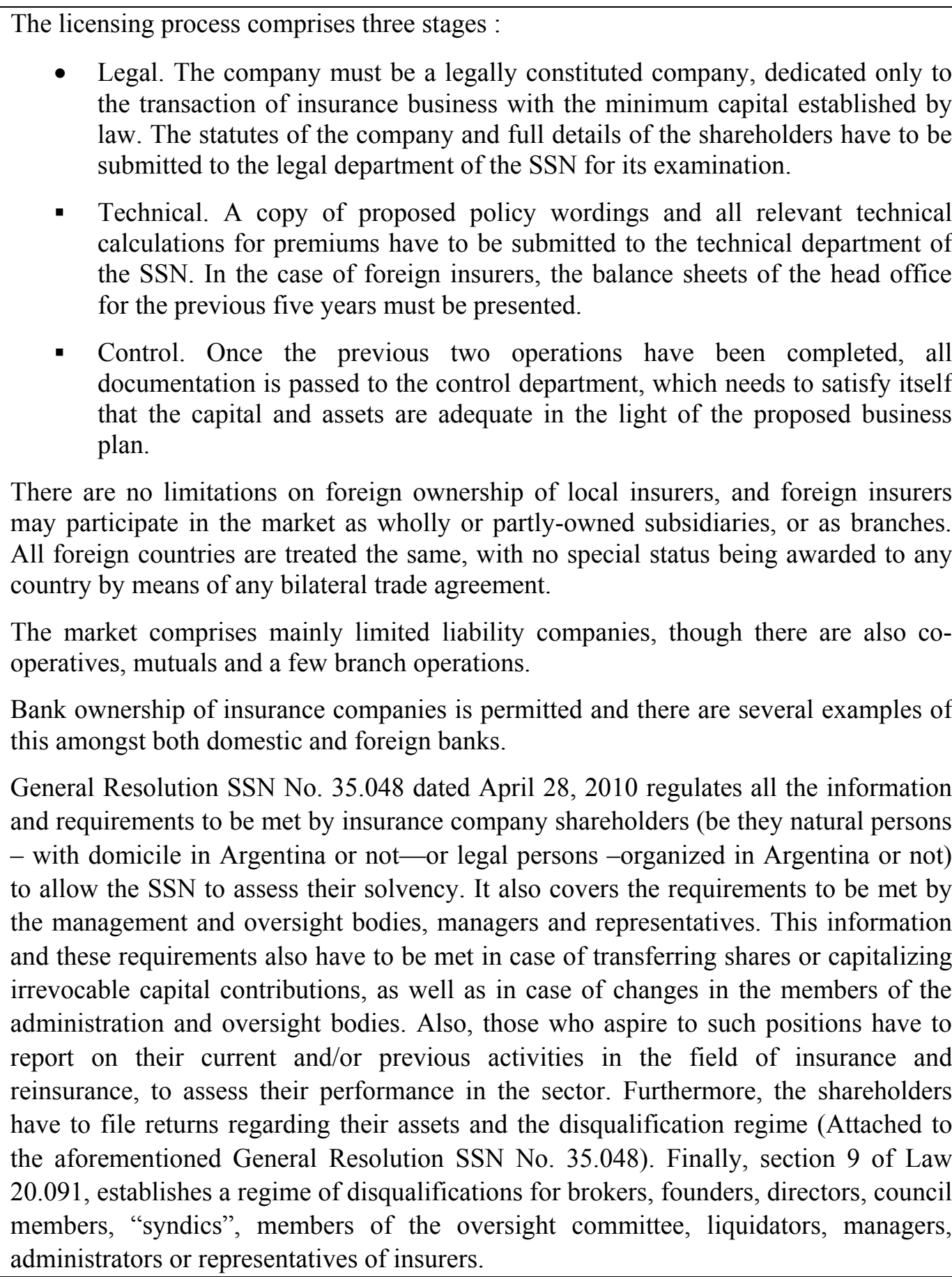 \\
\hline Assessment & $\mathrm{PO}$ \\
\hline Comments & $\begin{array}{l}\text { Insurance business is subject to licensing requirements and there are clear minimum } \\
\text { requirements. However, the licensing system needs to be improved according to ICP } 6 \text {. } \\
\text { Of particular importance are the necessity to require a three-year business plan, the } \\
\text { reinsurance aspects of the business plan, data on internal controls, fit and proper criteria, } \\
\text { and information on related party obligations and broader governance rules and } \\
\text { responsibilities. }\end{array}$ \\
\hline
\end{tabular}




\begin{tabular}{|c|c|}
\hline & $\begin{array}{l}\text { at least the immediate three years; the types of obligation the company proposes to } \\
\text { incur (life insurance) or the types of risk it proposes to cover (non-life insurance); the } \\
\text { basic principles of the company's reinsurance policy; the estimated setting-up costs and } \\
\text { the financial means to be used for this purpose; nor the projected development of } \\
\text { business and solvency margins. The evaluation of the business plan should include an } \\
\text { assessment of whether the applicant will be able to satisfy prudential requirements } \\
\text { regarding solvency, liquidity and internal control. } \\
\text { The application for the insurance license should include the opinion of the competent } \\
\text { supervisory authorities of the country where the applicant has its registered office, if the } \\
\text { founder is a foreign insurer. Such requirement should also be applicable to the } \\
\text { applications submitted by branches of insurance companies. Currently, there are no } \\
\text { formal procedures in place to request information from foreign supervisors prior to } \\
\text { granting a license to an insurer which belongs to an international group, nor is it the } \\
\text { practice to do so. }\end{array}$ \\
\hline Principle 7. & $\begin{array}{l}\text { Suitability of persons } \\
\text { The significant owners, board members, senior management, auditors and } \\
\text { actuaries of an insurer are fit and proper to fulfill their roles. This requires that } \\
\text { they possess the appropriate integrity, competency, experience and qualifications. }\end{array}$ \\
\hline Description & $\begin{array}{l}\text { General Regulations on Insurance Activity [Reglamento General de la Actividad } \\
\text { Aseguradora RGAA], paragraph 7, specifies the requirements for accrediting } \\
\text { shareholders, directors, managers, trustees and members of the supervisory council. The } \\
\text { IA sets impediments to hold the position of director in an insurance company. The } \\
\text { following are barred from being brokers, founders, directors, council members, } \\
\text { "syndics", members of the oversight committee, liquidators, managers, administrators } \\
\text { or representatives of insurers under this law, besides those included under the } \\
\text { disqualifications, incompatibilities and prohibition established by Law 19.550: those } \\
\text { convicted of crimes committed for profit or for crimes against property or public } \\
\text { confidence or for ordinary crimes, excluding culpable offenses with penalties of loss of } \\
\text { liberty or disqualification, for a time period equal to double that of the penalty, and } \\
\text { those being held in pretrial detention for the same crimes, until their final discharge; } \\
\text { those who have incurred in bankruptcy or bankruptcy prevention proceedings or debtors } \\
\text { in default of the entity. } \\
\text { Actuaries and auditors are not subject to fit and proper tests atall times (but only at the } \\
\text { time of registration). } \\
\text { In practice SSN does not appear to have the authority to disqualify non compliant } \\
\text { individuals after a license is granted and to prevent officers, directors and controllers } \\
\text { from holding positions that could lead to a conflict of interest. In addition, fit and } \\
\text { proper checks cannot be carried out in practice after issuing a license. }\end{array}$ \\
\hline Assessment & PO \\
\hline Comments & $\begin{array}{l}\text { The fit and proper requirements should be aligned with IAIS guidelines. In particular } \\
\text { the qualification requirements need to be made more specific to the financial sector and } \\
\text { prior experience should be at a suitably senior level. In addition, the history of } \\
\text { individuals (association with insurer failure, bankruptcy) should be taken into account } \\
\text { when assessing directorial appointments. } \\
\text { The legal framework needs to be improved to provide a formal foundation for sound }\end{array}$ \\
\hline
\end{tabular}




\begin{tabular}{|c|c|}
\hline & $\begin{array}{l}\text { and consistent requirements in a number of areas: } \\
\text { - Creation of fit and proper criteria for members of the board. Such requirements } \\
\text { are already applied in many countries and should become an integral part of the } \\
\text { ongoing assessment of the SSN risk management of the insurance companies. } \\
\text { - Establishment of fit and proper criteria for the auditor and actuary. SSN should } \\
\text { have the authority to assure that the competences and experience of the } \\
\text { members are proportionate and compatible with their responsibilities. } \\
\text { The assessment (fit and proper testing) of significant owners and key functionaries of an } \\
\text { insurer by the SSN should at a minimum take place as part of the licensing procedure } \\
\text { before the insurer is granted access to the insurance industry and - if the insurer is } \\
\text { already licensed - before a significant owner acquires its stake in the insurer or a key } \\
\text { functionary may exercise his/her duties and responsibilities with the insurer. The SSN } \\
\text { should collect sufficient and appropriate information to assess if the individual meets } \\
\text { the fit and proper requirements. } \\
\text { If the significant owner that is to be assessed is a corporate institution, the supervisors } \\
\text { should also review: } \\
\text { - its financial soundness and strengths (including its capital structure); } \\
\text { - the nature and scope of its business; } \\
\text { - its significant owners and key functionaries; } \\
\text { the group structure (if applicable) and organisation chart. }\end{array}$ \\
\hline Principle 8. & $\begin{array}{l}\text { Changes in control and portfolio transfers } \\
\text { The supervisory authority approves or rejects proposals to acquire significant ownership } \\
\text { or any other interest in an insurer that results in that person, directly or indirectly, alone } \\
\text { or with an associate, exercising control over the insurer. The supervisory authority } \\
\text { approves the portfolio transfer or merger of insurance business. }\end{array}$ \\
\hline Description & $\begin{array}{l}\text { The Law 19,550 (Law on Corporations) regulates aspects related to shareholders and } \\
\text { corporate oversight. SSN maintains registries of shareholders in insurance corporations } \\
\text { that include data on the holdings of each investor. Each share transfer is reviewed in } \\
\text { advance by SSN, which may comment on the proposed transaction. Prior authorization } \\
\text { by the Agency is required in order to affect the share transfer. In its review of share } \\
\text { transfers, SSN requests information about the assets of the proposed owners, their } \\
\text { resources, their activities in the insurance sector, and any possible incompatibilities. } \\
\text { SSN reviews whether the proposed owners of the share package have sufficient assets } \\
\text { and financial resources for the proposed purchase. This provision applies to corporate } \\
\text { investors as well as when a private investor buys a few shares in a company. } \\
\text { There are explicit provisions on ultimate rather than immediate beneficial owners. The } \\
\text { legal framework provides that no person shall, without the notification to SSN, acquire } \\
\text { or hold shares or any other interest in an insurer which results in that person exercising } \\
\text { control over that insurer. } \\
\text { SSN has the right to raise an objection towards notified share purchases in order to }\end{array}$ \\
\hline
\end{tabular}




\begin{tabular}{|c|c|}
\hline & $\begin{array}{l}\text { ensure the sound and prudent management of the insurer in which an acquisition is } \\
\text { proposed, having regard to the likely influence of the proposed acquirer on the insurer, } \\
\text { and taking into account the financial soundness of the proposed acquirer. } \\
\text { SSN Resolution } 30,742 \text { of October } 3,2005 \text { regulates total or partial portfolio transfer } \\
\text { and the merger of insurance businesses. As with share transfers, these operations must } \\
\text { also have prior express authorization by SSN. The voluntary portfolio transfers are } \\
\text { regulated (Law } 20,091 \text { Article } 46 \text { and } 47 \text { ) and require the usual notification of the } \\
\text { policyholders. The transfer of the portfolio requires an authorization from the SSN. The } \\
\text { proceeding is conditional on the final authorization of the SSN with the purpose of } \\
\text { safeguarding the interests of policy holders. For this reason, information is required on } \\
\text { the portfolio to be transferred, and there is a verification of the capacity of the assignee, } \\
\text { as well as a requirement to publish notices. } \\
\text { The approval of an insurance portfolio transfer is announced by SSN in a daily } \\
\text { newspaper of countrywide circulation. Insured persons are permitted to lodge } \\
\text { objections within } 3 \text { months following the day of the announcement. The insured who } \\
\text { have lodged an objection have the right to terminate the insurance contract. } \\
\text { SSN sets the conditions for the approval of total or partial transfer of a portfolio } \\
\text { (Resolution } 30,742 \text { ), in order to preserve the rights of policyholders (Law 20,091, } \\
\text { Articles } 46 \text { and } 47 \text {, and Resolution } 30,742 \text { ). } \\
\text { SSN has not yet issued guidelines on the processes to be followed in an application for } \\
\text { approval of portfolio transfer. }\end{array}$ \\
\hline Assessment & (2) \\
\hline Comments & $\begin{array}{l}\text { Financial groups containing potential controlling owners of insurers should be } \\
\text { sufficiently transparent so that supervision of the insurance group is not hindered (ICP } \\
\text { 17). } \\
\text { Guidelines should be issued outlining the processes to be followed in case of } \\
\text { application for approval of a portfolio transfer. }\end{array}$ \\
\hline Principle 9. & $\begin{array}{l}\text { Corporate governance } \\
\text { The corporate governance framework recognizes and protects rights of all } \\
\text { interested parties. The supervisory authority requires compliance with all } \\
\text { applicable corporate governance standards. }\end{array}$ \\
\hline Description & $\begin{array}{l}\text { Currently, there is no specific corporate governance framework in place. } \\
\text { The situation is helped somewhat by the fact that SSN inspectors do require companies } \\
\text { to follow some basic corporate governance requirements in their overall organizational } \\
\text { structure. } \\
\text { Also, SSN has focused on implementing legal provisions related to the corporate } \\
\text { governance of insurance companies. The following provisions are of note: } \\
\text { (a) SSN Resolution } 29,211 \text { of April } 22,2003 \text { and its supplementary provisions specify } \\
\text { the responsibilities of the insurers' administrative bodies in the formulation of } \\
\text { investment policies and procedures. }\end{array}$ \\
\hline
\end{tabular}




\begin{tabular}{|c|c|}
\hline & $\begin{array}{l}\text { (b) SSN Resolution } 31,231 \text { of July } 14,2006 \text { and its supplementary provisions specify } \\
\text { the responsibilities of the administrative body in setting standard administrative } \\
\text { procedures and internal controls that must be followed. } \\
\text { (c) SSN Resolution } 32,080 \text { of June } 25,2007 \text { and its supplementary provisions establish } \\
\text { the duties and responsibilities of the administrative body and of actuaries in setting rates } \\
\text { to be charged by insurers, follow-up regarding their adequacy, and measures to be taken } \\
\text { in cases of negative technical results. } \\
\text { (d) Resolution } 33,989 \text { of May } 15,2010 \text { (and its supplementary provisions) establishes a } \\
\text { custodial system with information on the investments of insurers regularly updated by } \\
\text { depository entities. }\end{array}$ \\
\hline Assessment & $\mathrm{PO}$ \\
\hline Comments & $\begin{array}{l}\text { The resolution on corporate governance is an urgent issue and it should specify a basic } \\
\text { set of corporate governance and internal control processes for insurers. These should } \\
\text { together identify major risks and the mitigation of operational risks (e.g. Preventing } \\
\text { claim, fraud, requiring double signatures, securing assets etc). In support of this, the IA } \\
\text { should specify that the actuary's statutory reports and all internal audit reports are made } \\
\text { available to the supervisory board. The board of directors should delegate its } \\
\text { responsibilities and establish a decision making process. The insurer has to establish a } \\
\text { division of responsibilities that will ensure a balanced power and authority, so that not } \\
\text { any individual could have unfettered powers of decision. The supervisory board should } \\
\text { also have oversight over investment policy and be required to review internal controls } \\
\text { and risk management systems at least once annually. } \\
\text { SSN should adopt a norm or guideline on Corporate Governance which suggests good } \\
\text { practices for the board of directors, key officers, internal and external auditing } \\
\text { functions, actuaries, etc. } \\
\text { A review of corporate governance practices will help to meet best practice in this field }\end{array}$ \\
\hline Principle 10. & $\begin{array}{l}\text { Internal control } \\
\text { The supervisory authority requires insurers to have in place the internal controls } \\
\text { that are adequate for the nature and scale of the business. The oversight and } \\
\text { reporting systems allow the board and management to monitor and control the } \\
\text { operations. }\end{array}$ \\
\hline Description & $\begin{array}{l}\text { The General Regulations on Insurance Activity and SSN Resolution } 31,231 \text { of July } 14 \text {, } \\
2006 \text { and its supplementary provisions state that it is the responsibility of the } \\
\text { administrative body to set standards on administrative procedures and internal controls } \\
\text { that are required to be followed. In addition, there are Law 20,091 and Generally } \\
\text { Accepted Standards For Internal Control (NCIGA). } \\
\text { Using the onsite inspections manuals, the examination team investigates whether an } \\
\text { insurance company has in place all the necessary internal controls aligned to the nature } \\
\text { and size of its business. The Resolution and regulation are implemented through special } \\
\text { on-site supervision inspections carried out by SSN. Such inspections are focused } \\
\text { specifically on internal control systems and include reviews of (i) internal auditing } \\
\text { procedures; (ii) solvency and internal controls. The internal auditing inspection ensures } \\
\text { that the Board takes the ultimate responsibility for the function and that internal auditors }\end{array}$ \\
\hline
\end{tabular}




\begin{tabular}{|c|c|}
\hline & $\begin{array}{l}\text { report to a designated member of the Board. Risk management inspections include a } \\
\text { review of companies' underwriting risk limits, investment policies, asset allocation; and } \\
\text { reinsurance programs. }\end{array}$ \\
\hline Assessment & $\mathrm{PO}$ \\
\hline Comments & $\begin{array}{l}\text { A review of practices, followed by the publication of Guidelines on Corporate } \\
\text { Governance, would be very helpful to implement practices that will improve } \\
\text { compliance with expectations in the area of monitoring internal controls. } \\
\text { The internal and external audit, actuarial and compliance functions are part of the } \\
\text { internal control apparatus of an insurance company. Thus, the SSN should not rely only } \\
\text { on auditors. Rather, it must test adherence to the entire sprectrum of internal controls as } \\
\text { well as to aplicaple laws. In view of the absence of a more risk-based approach to } \\
\text { supervision, there is a need to regulate corporate governance and internal control } \\
\text { functions. This approach should be changed with the more Risk Based Supervision and } \\
\text { more emphasis on internal controls should be given by SSN staff. Although internal } \\
\text { control requirementss can be imposed without risk-based supervision, ideally the two } \\
\text { things should go hand in hand. }\end{array}$ \\
\hline \multicolumn{2}{|c|}{ Ongoing Supervision } \\
\hline Principle 11. & $\begin{array}{l}\text { Market analysis } \\
\text { Making use of all available sources, the supervisory authority monitors and } \\
\text { analyses all factors that may have an impact on insurers and insurance markets. It } \\
\text { draws the conclusions and takes action as appropriate. }\end{array}$ \\
\hline Description & $\begin{array}{l}\text { In Argentina industry associations are very segmented, reflecting very diverse sectoral } \\
\text { objectives and interests. For that reason the law saw fit to assign to the SSN the power } \\
\text { to collect and publish information, to guarantee that it is objective, comprehensive and } \\
\text { global for the sector. Besides, the data gathered by the SSN is effectively used for } \\
\text { decision-making at three levels: } \\
\text { - first of all by the agency itself, as regulator and for supervisory purposes; } \\
\text { - by the general public and users in particular, thorugh the publication of } \\
\text { indicators which illustrate the situation of the entities from different } \\
\text { perspectives (financial, equity, production, litigation, etc); and } \\
\text { by the insurers themselves, their shareholders, and administration bodies, which } \\
\text { usually require documented certifications of the information published. } \\
\text { Moreover, the various industry associations produce works targeting specifically at the } \\
\text { commercial modalities of their members, using the information that is published by our } \\
\text { agency which, on the other hand and because of its value, is reproduced, or serves as a } \\
\text { basis for the sector's specialized publications. } \\
\text { The Insurance Law } 20,091 \text { requires publication of annual statistics about the insurance } \\
\text { market. SSN publishes quarterly and annually market reports which are based on data } \\
\text { collected from insurance companies. SSN also publishes semi-annual tables without the } \\
\text { key parameters and the ratios of the insurance market. In addition, the industry } \\
\text { publishes an Annual Report through the Associations. } \\
\text { SSN annually publishes, on its website, a report on the Insurance Sector which includes } \\
\text { aggregate analyses of the main developments in the sector. SSN also publishes quarterly }\end{array}$ \\
\hline
\end{tabular}




\begin{tabular}{|c|c|}
\hline & $\begin{array}{l}\text { reports on "Insurance sector key data" which present aggregated information on the } \\
\text { insurance sector structure, aggregate main balance sheet and profit and loss account } \\
\text { items, and capital adequacy. Additional insurance statistics are published by the } \\
\text { Ministry of Finance on its website. }\end{array}$ \\
\hline Assessment & $\mathrm{PO}$ \\
\hline Comments & $\begin{array}{l}\text { The level of aggregated publishable market data appears to be excessive; detailed data } \\
\text { reporting results in considerable costs for the industry without obvious benefit. The } \\
\text { SSN should consider producing aggregate analyses of the main developments with } \\
\text { accurate and timely data (published by SSN but meeting information needs of all } \\
\text { stakeholders) which is up-to-date and is published more than once a year. } \\
\text { The market analysis should not only include past developments and the present } \\
\text { situation, but also aim to identify trends and possible future scenarios and issues, so that } \\
\text { the supervisory authority is well prepared to take action at an early stage, if required. } \\
\text { There is no such approach in the SSN. The SSN should carry out scenario analysis to } \\
\text { understand the impact of hypothetical macro-economic scenarios on profitability and } \\
\text { growth of insurers. } \\
\text { Market analysis is based on past developments and the present situation, but should also } \\
\text { consider future developments. Among the sources of prospective information are } \\
\text { business plans of insurers. }\end{array}$ \\
\hline Principle 12. & $\begin{array}{l}\text { Reporting to supervisors and off-site monitoring } \\
\text { The supervisory authority receives necessary information to conduct effective off- } \\
\text { site monitoring and to evaluate the condition of each insurer as well as the } \\
\text { insurance market. }\end{array}$ \\
\hline Description & $\begin{array}{l}\text { Insurers are required to provide SSN with details of their solvency, capital, debts, } \\
\text { liquidity and underwriting results. On an annual basis, within } 30 \text { days of the annual } \\
\text { general meeting which must take place by the end of October each year, companies } \\
\text { must send to the SSN their report and accounts including balance sheet and profit \& } \\
\text { loss account, accompanied by an independent auditor's report. Monthly report on the } \\
\text { investment portfolio and quarterly report on reinsurance. The fiscal year runs from } 1 \\
\text { July to } 30 \text { June. Branches of foreign insurers may submit their accounts on a fiscal year } \\
\text { basis or the basis used by their head office, within six months of the end of the chosen } \\
\text { annual period. In addition to the above, SSN may request detailed accounting } \\
\text { information at any time in order to verify the financial situation of an insurer. } \\
\text { The SSN uses the data produced in its desk analysis and has a broad range of indexes } \\
\text { that are published on a quarterly basis (http://www.ssn.gov.ar/storage/Info). The scope } \\
\text { of information should be changed to produce more useable data that the SSN could use } \\
\text { in its off-site analysis. It is also important to have comprehensive details on a broad } \\
\text { range of financial analysis ratios to be used by the SSN. In addition, revised reporting } \\
\text { forms should be prepared aligned with a risk-based supervision framework. it is also } \\
\text { imperative that the insurance supervisor work closely with the accounting and auditing } \\
\text { professionals and insurance companies to improve the quality and reliability of financial } \\
\text { information. Certain reports (e.g. detailing asset movements, including for unrated } \\
\text { reinsurers and insurers at risk) should be submitted as well. }\end{array}$ \\
\hline
\end{tabular}




\begin{tabular}{|c|c|}
\hline & $\begin{array}{l}\text { Accounts are currently prepared in accordance with Argentinean GAAP. Foreign } \\
\text { companies may apply IAS or their national GAAP but reconciliation to Argentinean } \\
\text { GAAP is required. International Financial Reporting Standards (IFRS) will apply to all } \\
\text { companies listed on the stock exchange starting on January 1, 2012; the intention is to } \\
\text { apply it also to the insurance market but no timetable for such a development has been } \\
\text { established. } \\
\text { Currently there are no requirements for actuarial reports, although a life and non-life } \\
\text { insurance company may be asked to provide an actuarial report on a specific topic. The } \\
\text { independent actuaries write reports connected with review procedures and issue reports } \\
\text { on: a) the risk retention and underwriting policy and b) compliance with the levels of } \\
\text { risk retention, in these two cases in order for the reports to be submitted for the approval } \\
\text { of new technical-contractual conditions. Finally, actuaries issue reports at the time of } \\
\text { presenting the accounting statements on the setup of some reserves, e.g. IBNR. } \\
\text { Primitive system of early warning tests (whether quantitative or qualitative) is used to } \\
\text { predict potential financial difficulties in individual companies. } \\
\text { Financial reports to shareholders are prepared on the same basis as those presented to } \\
\text { the SSN. Insurers currently submit up to } 25 \text { different forms to the SSN. These would } \\
\text { appear to be adequate for monitoring purposes, subject to data accuracy, timeliness and } \\
\text { the availability of sufficient computing and human resources for proper analysis. } \\
\text { In additional to the annual financial statements, companies are obliged to file monthly } \\
\text { and semiannual reports providing supplementary information on their operations. Some } \\
\text { of this material is useful for statistical purposes only and would not be of great } \\
\text { assistance in the analysis of the financial condition of the companies. There is no } \\
\text { information collection on a group-wide basis. Timeliness and accuracy are of } \\
\text { importance if the objective is to make timely decisions to protect policyholders. } \\
\text { Currently financial information must be submitted in hard copy. }\end{array}$ \\
\hline Assessment & $\mathrm{PO}$ \\
\hline Comments & $\begin{array}{l}\text { As a general rule, statistical information should be collected with less frequency while } \\
\text { material that is crucial to analysis should be collected more frequently. } \\
\text { The scope of information should be changed to produce more useable data that SSN } \\
\text { could use in its off-site analysis. It is important to have comprehensive details, which } \\
\text { would enable the calculation of a broad range of financial analysis ratios used by SSN. } \\
\text { To facilate the gathering of such information, revised reporting forms should be } \\
\text { prepared. } \\
\text { SSN should develop an automated system for checking the data submitted and } \\
\text { producing the basic analytical information (e.g. IRIS ratios) needed by the of site } \\
\text { monitoring team. Such automated system could also be the basis for an advance early } \\
\text { warning system. } \\
\text { Supervisory judgments made by the offsite department should be timely and robust } \\
\text { enough to ensure early supervisory intervention aligned with the risk of the insurance } \\
\text { company. Due to the lack of risk based approach and the absence of early warning } \\
\text { system, it is possible that the SSN may not be able to identify weaknesses and problems }\end{array}$ \\
\hline
\end{tabular}




\begin{tabular}{|c|c|}
\hline & 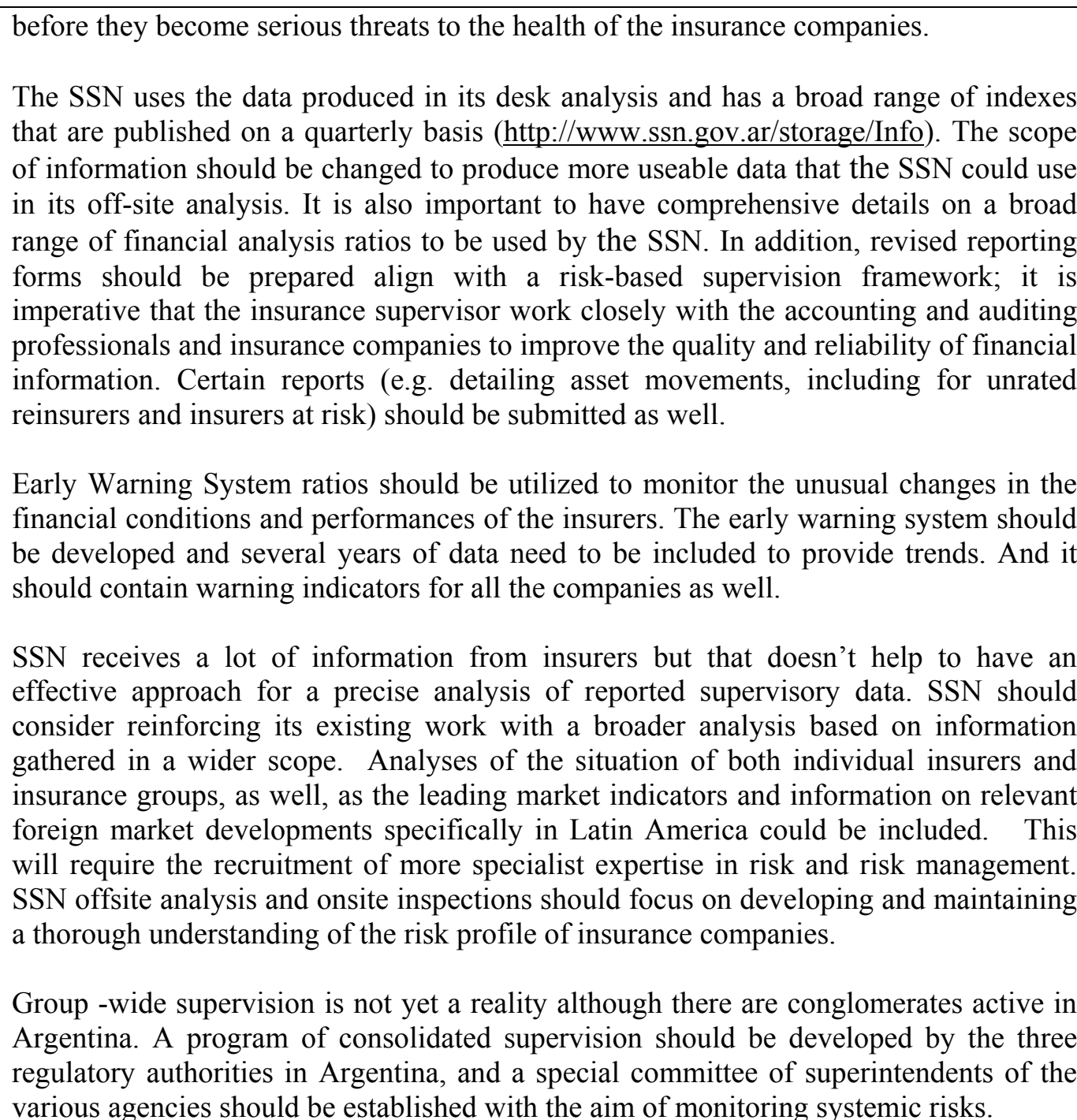 \\
\hline Principle 13. & $\begin{array}{l}\text { On-site inspection } \\
\text { The supervisory authority carries out on-site inspections to examine the business of an } \\
\text { insurer and its compliance with legislation and supervisory requirements. }\end{array}$ \\
\hline Description & $\begin{array}{l}\text { SSN has the power and full freedom to perform at any time on-site inspections of the } \\
\text { insurance market participants, including intermediaries. The off-site analysis process } \\
\text { helps to identify those companies where an early inspection is required. The legal } \\
\text { framework provides that all companies operating in the market must be inspected at } \\
\text { least once every } 36 \text { months. The timing of the visit takes into account the date of the } \\
\text { last routine inspection, the minimum capital requirement, the number of claims filed } \\
\text { against the insurer, and the number of lawsuits currently pending against it. } \\
\text { SSN may conduct on-site inspections in practice on either a full scale, or on certain } \\
\text { operational fields of the insurer. Consideration is given to minimum capital requirement } \\
\text { and assessment of current solvency. After each inspection is completed, a report on } \\
\text { findings is written and sent to the company management by the Superintendent } \\
\text { including notification of any existing violations or breaches. Then sanctions are } \\
\text { implemented by SSN, if necessary. }\end{array}$ \\
\hline
\end{tabular}




\begin{tabular}{|c|c|}
\hline & $\begin{array}{l}\text { As part of the offsite review process, quarterly solo and consolidated returns are } \\
\text { analysed and an Executive Summary (ES) is prepared. The data included in the ES } \\
\text { report are generated from the prudential returns and post-inspection letters are issued by } \\
\text { the SSN. }\end{array}$ \\
\hline Assessment & LO \\
\hline Comments & 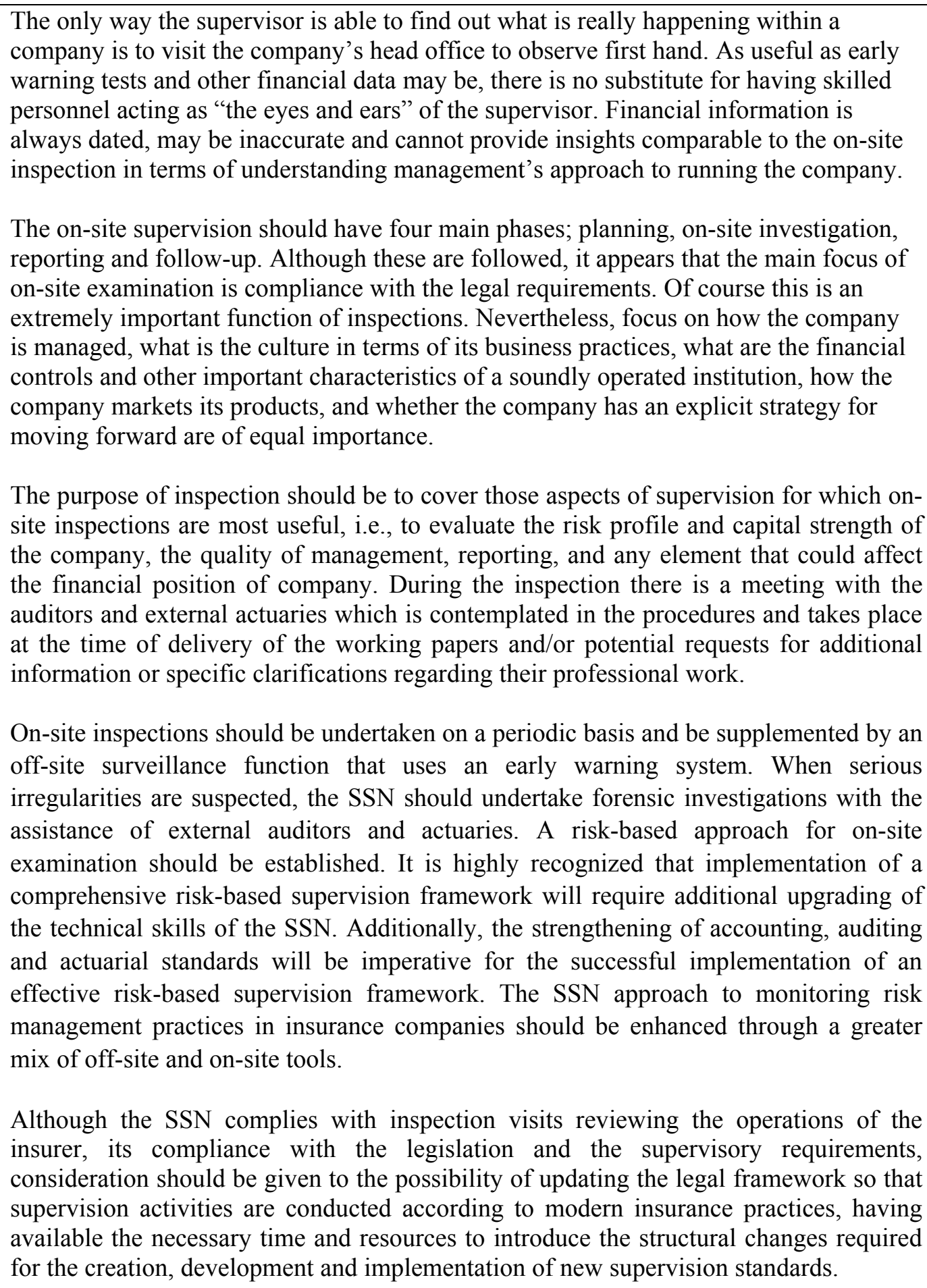 \\
\hline
\end{tabular}




\begin{tabular}{|c|c|}
\hline Principle 14. & $\begin{array}{l}\text { Preventive and Corrective Measures } \\
\text { The supervisory authority takes preventive and corrective measures that are } \\
\text { timely, suitable and necessary to achieve the objectives of insurance supervision. }\end{array}$ \\
\hline Description & $\begin{array}{l}\text { There has been only one case of insurance company failure over the last decade. If SSN } \\
\text { were to adopt a risk classification system, it should be able to take more timely } \\
\text { preventive and corrective action in any future cases. } \\
\text { Auditors and actuaries are bound to report on the difficulties of the insurers that they } \\
\text { detect. These are indicated in the reports attached to the corresponding financial } \\
\text { statements. If they fail to report on findings or difficulties that are detected later by the } \\
\text { SSN in the supervisory process, a separate proceeding is started to assess the } \\
\text { performance of the professional involved. }\end{array}$ \\
\hline Assessment & $\mathrm{PO}$ \\
\hline Comments & $\begin{array}{l}\text { This ICP is a fundamental component of any effective supervision, including a risk- } \\
\text { based supervisory model, and represents a basic gap in the current Argentine regulatory } \\
\text { and supervisory structure. } \\
\text { Although legislation governing SSN work provides it with wide range of remedies to } \\
\text { address actual or potential noncompliance by an insurer, these powers do not create an } \\
\text { expectation that companies will report problems at an early stage. In addition, the } \\
\text { auditors and actuaries don't have duties to report concerns to SSN. For example, the } \\
\text { auditors employed by long term (liability) insurers must report to SSN in case of } \\
\text { termination of their appointment and on any potential contravention of financial } \\
\text { soundness requirements. Certain communications by auditors to companies must be } \\
\text { copied to the SSN. SSN should plan to meet auditors as part of its risk-based onsite } \\
\text { work. } \\
\text { The SSN should make use of adequate instruments to enable timely preventive and } \\
\text { corrective measures if an insurer fails to operate in a manner that is consistent with } \\
\text { sound business practices or regulatory requirements. There should be a progressive } \\
\text { escalation of action or remedial measures if the problems become worse or if } \\
\text { management of the insurer ignores requests from the SSN to take corrective action. } \\
\text { When the law undergoes its next revision, powers for early intervention, based on a } \\
\text { regulatory ladder (i.e., risk assessment based on multiple inputs), should be } \\
\text { incorporated. This would need to be accompanied by a strengthening of the data } \\
\text { gathering and offsite analytical and monitoring capacity of SSN. In addition the on-site } \\
\text { inspectors would need to take more of a control- and risk-assessment approach and less } \\
\text { of a financial auditing approach. } \\
\text { The power of the supervisor to take preventive and corrective measures proportionate to } \\
\text { the circumstances should be stated in the law. A manual should be prepared which } \\
\text { provides the details on prompt corrective actions and a ladder for compliance to ensure } \\
\text { consistency in the way insurers are sanctioned, so that similar violations and } \\
\text { weaknesses could be subject to similar preventive and corrective measures. }\end{array}$ \\
\hline
\end{tabular}




\begin{tabular}{|l|l|}
\hline Principle 15. & $\begin{array}{l}\text { Enforcement or sanctions } \\
\text { The supervisory authority enforces corrective action and, where needed, imposes } \\
\text { sanctions based on clear and objective criteria that are publicly disclosed. }\end{array}$ \\
\hline Description & $\begin{array}{l}\text { The legislation provides SSN with a range of sanctions it can apply when dealing with a } \\
\text { problem company - letter of notice, warning and fines; partial or up to three months } \\
\text { suspension of business; and even complete withdrawal of the authority to issue policies. } \\
\text { In the case of intermediaries the sanctions are letter of notice, warning, fine of up to five } \\
\text { thousand pesos and disqualification for up to five years. } \\
\text { The SSN has the power to prevent the writing of new business, withholding approval for } \\
\text { new activities or acquisitions, and revoking the license of an insurer, but only has partial } \\
\text { authority to interfere in the company's management. } \\
\text { Sections } 31 \text { and } 86 \text { of Law 20.091 estaablish a catalogue of objective situations of } \\
\text { danger which require the prudential adoption of preventive measures. }\end{array}$ \\
\hline Assessment & $\begin{array}{l}\text { TO SSN has limited authority to take action to protect an insurer within its jurisdiction } \\
\text { that belongs to a group from financial difficulties in other parts of the group and cannot } \\
\text { interfere with the situation before the risks materializes. Thus there is a need for a } \\
\text { detailed and correctly defined regulation. }\end{array}$ \\
\hline Comments & $\begin{array}{l}\text { The SSN can not arrange for compulsory transfer of the obligations under policies from } \\
\text { a failing insurer to another insurer that accepts this transfer. } \\
\text { The SSN should have full power to take control of the insurer, or appoint other } \\
\text { specified officials or receivers for the task, and make such arrangements for the benefit } \\
\text { of the policyholders as deemed necessary }\end{array}$ \\
\hline
\end{tabular}




\begin{tabular}{|c|c|}
\hline Principle 16. & $\begin{array}{l}\text { Winding-up and exit from the market } \\
\text { The legal and regulatory framework defines a range of options for the orderly exit } \\
\text { of insurers from the marketplace. It defines insolvency and establishes the criteria } \\
\text { and procedure for dealing with insolvency. In the event of winding-up proceedings, } \\
\text { the legal framework gives priority to the protection of policyholders. }\end{array}$ \\
\hline & $\begin{array}{l}\text { The conditions for winding up and exit from the market and withdrawing licenses are set } \\
\text { forth in the Insurance Law 20,091, Article 49-52. } \\
\text { When the insurer voluntarily decides to dissolve the enterprise, the liquidation shall } \\
\text { be conducted by its statutory bodies, without prejudice to oversight by the SSN. If } \\
\text { the insurer does not proceed immediately to liquidation, or if protection of the } \\
\text { interests of policyholders so indicates, the SSN may request that an ordinary judge with } \\
\text { jurisdiction in the area, orders the conversion of the voluntary liquidation into a mandated } \\
\text { one, appointing the SSN as liquidator. The decision will include citation of the insurance } \\
\text { company in a verbal hearing convened for this purpose, and any appeal shall have only } \\
\text { devolutive effect. When the liquidation is a consequence of a revocation imposed by the } \\
\text { supervisory authority, the latter shall assume responsibility through the person designated } \\
\text { by a regular judge competent in this. } \\
\text { In the event of application of Articles } 50 \text { and } 51 \text {, the supervisory authority shall ensure that } \\
\text { the liquidation is consistent with provisions for commercial insolvency proceedings, and in } \\
\text { said proceedings it shall have all the powers of a receiver. } \\
\text { It may rescind an insurance contract with fifteen (15) days' prior notice, notifying the } \\
\text { policyholders by certified letter with return receipt requested or by other similar means. } \\
\text { The insurer is responsible for the losses incurred in the interim unless the policyholder is } \\
\text { able to arrange for another insurance policy in its stead. In the case of life insurance, } \\
\text { arrangements will be made in advance for the assignment of rights through a bidding } \\
\text { process to be determined. If such assignment is not possible, the provisions of the previous } \\
\text { paragraph apply. }\end{array}$ \\
\hline & $\mathrm{LO}$ \\
\hline & $\begin{array}{l}\text { The basic general framework does not provide for a guarantee fund in the case of a } \\
\text { company's insolvency, except to cover the benefits that an insurer against work-related } \\
\text { risks fails to deliver because of its liquidation. } \\
\text { There is an adequate regulatory framework for the exclusion of insurers from the } \\
\text { market and there are specific procedures for dealing with insolvency and liquidation of } \\
\text { the companies. }\end{array}$ \\
\hline Principle 17. & $\begin{array}{l}\text { Group-wide supervision } \\
\text { The supervisory authority supervises its insurers on a solo and a group-wide basis. }\end{array}$ \\
\hline Description & $\begin{array}{l}\text { Several measures show that the SSN has no access to the structures of the supervised } \\
\text { insurance groups and conglomerates. First, there is no legal certainty about what } \\
\text { constitutes an insurance group or conglomerate. Secondly, information on the structure } \\
\text { and activities of the group entities are not included in the mandatory financial and } \\
\text { prudential returns (group-wide assessment and supervision should not be limited to } \\
\text { financial indicators such as capital adequacy and risk concentration, and should also } \\
\text { cover the consolidated financial statements, financial statements of subsidiary } \\
\text { undertakings or of undertakings which the insurance company has close links to, } \\
\text { management structure, fit and proper testing, and legal issues). Thirdly, the SSN has no }\end{array}$ \\
\hline
\end{tabular}




\begin{tabular}{|c|c|}
\hline & $\begin{array}{l}\text { power to do the regular assessment of group structures during on-site inspections and } \\
\text { discussions with institutions. Finally, theSSN does not request information from other } \\
\text { foreign and domestic authorities. } \\
\text { SSN has no power to obtain information from and about the activities of the entities of a } \\
\text { conglomerates or financial holding company, both in the terms of domestic and cross- } \\
\text { border entities. Such powers should be stated in the Insurance legal framework. } \\
\text { Supervision of banking, insurance and capital markets is carried out by independent } \\
\text { agencies in Argentina. At the same time, there is no systematic communication of } \\
\text { supervisory actions for entities of a conglomerate or financial group across the various } \\
\text { sectors nor are findings shared systematically. Nevertheless, assessors consider that } \\
\text { there is an urgent need for coordinated supervisory methodologies across sectors. } \\
\text { Assessors note that SSN has not always made full use of its powers to supervise the } \\
\text { foreign activities of insurance companies, for example by performing on-site } \\
\text { inspections abroad. }\end{array}$ \\
\hline Assessment & $\mathrm{NO}$ \\
\hline Comments & $\begin{array}{l}\text { Group reporting is undeveloped; the SSN should extend the reporting it requires of the } \\
\text { largest insurance groups to all group entities and should ensure that group companies } \\
\text { undertaking investment, asset management, pension business, as well as insurance, are } \\
\text { included in the scope of consolidated supervision. } \\
\text { As a first step, legislation should enable the SSN to request whatever information is } \\
\text { required. In addition, the SSN should implement the following measures to facilitate } \\
\text { group supervision: } \\
\text { - undertake solvency calculation on a group wide basis for all insurance groups } \\
\text { - provide a clear definition of an insurance group so that the SSN and insurers } \\
\text { can determine: which groups are considered to be insurance groups or financial } \\
\text { conglormerates, as well as the scope of the supervision } \\
\text { - define an approach to calculate group financial conditions } \\
\text { - prescribe the remedial action that can be taken against solo entity that should } \\
\text { also be available in respect to an insurance group. } \\
\text { The SSN should be able to conduct supervision, as a supplement to solo supervision, at } \\
\text { at a minimum, a group level, and at intermediate level as appropriate. It should have } \\
\text { adequate policies on and supervisory oversight of; } \\
\text { - group structure and interrelationships, including ownership and management } \\
\text { - structure } \\
\text { - rapital adequacy } \\
\text { - insurance and risk concentration } \\
\text { - possible legal liabilities } \\
\text { internal control mechanism and risk management processes, including reporting } \\
\text { lines and fit and proper testing of senior management. }\end{array}$ \\
\hline
\end{tabular}




\begin{tabular}{|c|c|}
\hline \multicolumn{2}{|c|}{ Prudential Requirements } \\
\hline Principle 18. & $\begin{array}{l}\text { Risk assessment and management } \\
\text { The supervisory authority requires insurers to recognize the range of risks that } \\
\text { they face and to assess and manage them effectively. }\end{array}$ \\
\hline Description & $\begin{array}{l}\text { There are no requirements or guidelines on risk management for insurance companies. } \\
\text { In practice, the adequacy of company's risk management functions is checked against } \\
\text { the SSN Manual for on-site inspections. The Manual however is somewhat vague and } \\
\text { would require considerable further work to become an effective tool for the supervision } \\
\text { of risk management in insurance companies. Under this manual insurers are not even } \\
\text { required to report on their risk management practices (for instance, there are no } \\
\text { questions on risk management such as whether the insurer has a risk management } \\
\text { function and what are the company's major risk areas.) } \\
\text { In the area of internal controls, the SSN relies on reporting by insurers and its offsite } \\
\text { and onsite supervisory processes (which should be enhanced by the risk-based } \\
\text { supervision model) to detect and deal with risk assessment and risk management } \\
\text { weaknesses. Such issues are also discussed with auditors. The SSN staff is therefore } \\
\text { fully aware of the importance of effective supervision and there is importance of risk } \\
\text { management and the need to ensure that it is adequate -and that, supervisors must rely } \\
\text { on company management to help ensure overall compliance. }\end{array}$ \\
\hline Assessment & $\mathrm{PO}$ \\
\hline Comments & $\begin{array}{l}\text { The reporting by insurers and its offsite and onsite supervisory processes to detect and } \\
\text { deal with risk assessment and risk management weaknesses are part of the supervisory } \\
\text { processs. } \\
\text { Effective supervision begins with the risk-based supervisory model for insurers. Under } \\
\text { this model, supervisors are required to assess the effectiveness of risk management as a } \\
\text { mitigating factor for inherent risks. Areas of potential weakness are then followed up in } \\
\text { onsite work and if confirmed, are reflected in reports to management and in required } \\
\text { action. } \\
\text { Firstly and urgently there is a need for SSN to provide more feedback and guidance to } \\
\text { companies on its observations and experience of good and bad risk management } \\
\text { practices. A prudential regulation establishing minimum risk management } \\
\text { requirements for insurers is also required.The regulation should require that risk } \\
\text { management practices be appropriate to the size and nature of an insurer's business. In } \\
\text { doing so, the SSN would be able check that insurers have in place comprehensive risk } \\
\text { management policies and systems capable of promptly identifiying, measuring, } \\
\text { assessing, reporting, and controlling their risks. The risk management policies and risk } \\
\text { control systems should be appropriate for the complexity, size and nature of the } \\
\text { insurer's business. }\end{array}$ \\
\hline
\end{tabular}




\begin{tabular}{|c|c|}
\hline Principle 19. & $\begin{array}{l}\text { Insurance activity } \\
\text { Since insurance is a risk taking activity, the supervisory authority requires insurers to } \\
\text { evaluate and manage the risks that they underwrite, in particular through reinsurance, } \\
\text { and to have the tools to establish an adequate level of premiums. }\end{array}$ \\
\hline Description & $\begin{array}{l}\text { The SSN has specific rules which require that the entities communicate their risk } \\
\text { underwriting policy (point } 24.1 \text { of the RGAA) to the SSN every time an insurer decides } \\
\text { to request the approval of new technical-contractual terms.Insurers are required to } \\
\text { establish their underwriting and risk retention policy through their Board. The SSN, by } \\
\text { means of on site inspections, verifies compliance with this rule. } \\
\text { The SSN receives quarterly information on the Particular Conditions of all the } \\
\text { automatic reinsurance contracts in force in the market (resolution } 21893 \text { ). Based on this } \\
\text { information, the SSN conducts an analysis of the retention levels of each insurer, and } \\
\text { compares them to the rule which sets parameters (resolution } 32708 \text { ). It also makes } \\
\text { additional inquiries to ultimately verify whether insurers maintain an adequate level of } \\
\text { risk retention in connection with their economic-financial capacity. In case on site } \\
\text { controls are required, the SSN sends inspections and, beginning with the effective } \\
\text { underwriting of business, extends the analysis to determine whether there is an adequate } \\
\text { risk transfer to reinsurance. } \\
\text { In respect to reinsurance arrangements, detail on companies' arrangements are collected } \\
\text { via the annual return- data on reinsurance premiums paid, reinsurance recoveries, } \\
\text { extent of catastrophe cover etc. There are also extensive statements on overall } \\
\text { reinsurance strategy. These statements have to be signed by the actuary and auditor. } \\
\text { However, individual reinsurance arrangements are not checked, unless there is a } \\
\text { particular concern. } \\
\text { There are no specific requirements in relation to pricing policies or their approval by } \\
\text { boards of directors. The SSN's approach to insurance risk relies on: } \\
\text { - management responsible for the adequacy of reserving and financial condition } \\
\text { generally; } \\
\text { - the duties and obligations placed on the external auditor and actuary; the } \\
\text { external auditors and actuary must certify the soundness of the insurer's } \\
\text { insurance activities; } \\
\text { information reported by insurers on their insurance activities and reinsurance } \\
\text { arrangements as part of their regular reporting; and } \\
\text { of the annual and quarterly reporting, followed up by communications with the } \\
\text { company; and onsite work to assess company processes in practice. }\end{array}$ \\
\hline Assessment & $\mathrm{PO}$ \\
\hline Comments & $\begin{array}{l}\text { Although it is legally empowered to do so, the SSN has not enough technical capacity } \\
\text { to check whether the insurer has a clear strategy to mitigate and diversify risks, whether } \\
\text { by arranging appropriate reinsurance cover or using other risk transfer arrangements } \\
\text { consistent with its capital position. Although the issue is addressed by the insurance } \\
\text { legislation, in practice there are no specific guidelines on risk retention/risk transfer } \\
\text { policies neither for insurers' risk portfolios by specific lines of business nor for the } \\
\text { aggregate risk portfolio as a whole. The existing resolution only addresses individual } \\
\text { risk retention policy. }\end{array}$ \\
\hline
\end{tabular}




\begin{tabular}{|c|c|}
\hline & $\begin{array}{l}\text { The SSN should be able to review the methodology used by the insurer in setting the } \\
\text { premiums to ensure that they are established on reasonable assumptions to enable the } \\
\text { insurer to meet its commitments. The Actuarial Reports should be prepared annually } \\
\text { and be sent to the SSN including the methodology chosen for the determination of } \\
\text { premiums. } \\
\text { As the SSN does not use a risk-based approach, they usually review the overall position } \\
\text { of the company -considering the adequacy of reserves and whether the company is } \\
\text { meeting the Capital Adequacy Requirement. More detailed work should be done in } \\
\text { response to concerns or where, for example, a company is moving into new areas of } \\
\text { business. SSN should develop and introduce detailed inspection manuals and regulatory } \\
\text { tools that can guide the supervisor's analysis of companies' net risk } \\
\text { retention/reinsurance policies for portfolios of insurance risk. }\end{array}$ \\
\hline Principle 20. & $\begin{array}{l}\text { Liabilities } \\
\text { The supervisory authority requires insurers to comply with standards for } \\
\text { establishing adequate technical provisions and other liabilities, and making } \\
\text { allowance for reinsurance recoverable. The supervisory authority has both the } \\
\text { authority and the ability to assess the adequacy of the technical provisions and to } \\
\text { require that these provisions be increased, if necessary. }\end{array}$ \\
\hline Description & $\begin{array}{l}\text { SSN requires insurers to comply with the standards for establishing the adequacy of the } \\
\text { technical provisions as stated in the Insurance Law No: } 20,091 \text { Article } 33-35 \text {. Article } \\
33 \text { allows the SSN to verify the reserves and to request insurers to correct them if } \\
\text { needed. Technical reserves must be established in accordance with the provisions of } \\
\text { Article } 39 \text { of the insurance law and accompanying regulations. The principal provisions } \\
\text { are in respect of uncollectable premiums, unearned premium reserve, deferred } \\
\text { acquisition costs, premium insufficiency reserve, collection expenses provision, } \\
\text { outstanding claims provision and incurred but not reported (IBNR) losses. Unearned } \\
\text { premium reserves and outstanding claims reserves, including IBNR, are set up gross of } \\
\text { reinsurance, with the reinsurance ceded being accounted for separately. } \\
\text { Regulation No } 33.526 \text { of October } 2008 \text { made a change to the criteria for reserving cases } \\
\text { under mediation involving third party liability policies and cases under mediation and } \\
\text { litigation involving professional liability covers. By means of Regulation } 34.144 \text { of } 30 \\
\text { June } 2009 \text { the SSN introduced changes to the calculation formulae for outstanding } \\
\text { claims awaiting judgment or arbitration. The legislation establishes valuation criteria to } \\
\text { be used for motor and general third party liability claims, indicating minimum amounts } \\
\text { to be reserved. } \\
\text { Changes were made to the calculation of workers' compensation reserves by means of } \\
\text { Regulation No } 34.642 \text { of } 23 \text { December } 2009 \text { following the changes made to the } \\
\text { workers' compensation legislation in respect of benefit levels. } \\
\text { Regulation No } 34.717 \text { of } 21 \text { January } 2010 \text { introduced changes to the formula for the } \\
\text { calculation of the premium insufficiency reserve. } \\
\text { There are no catastrophe reserves required. } \\
\text { The basis for the reserves of life insurers, however, is calculated in accordance with the } \\
\text { formula applied by the insurer's actuaries. These formulae must take into account the } \\
\text { sufficiency of reserves to meet an insurer's obligations to its insureds from both short- }\end{array}$ \\
\hline
\end{tabular}




\begin{tabular}{|c|c|}
\hline & $\begin{array}{l}\text { term and long-term contracts (over one year). } \\
\text { The law defines what investments can be considered as representative to back up the } \\
\text { technical reserves and the required supporting capital. The adequacy of the technical } \\
\text { reserves is periodically reviewed during on and off site examinations. } \\
\text { Insurance company liabilities are subject to audit as part of the annual audit } \\
\text { requirement. The SSN can summon the actuary to appear before the Agency working } \\
\text { papers which are the evidence of how the tasks were determined (these have to be } \\
\text { retained during six (6) business years as a minimum), and provide the clarifications and } \\
\text { additional explanations deemed necessary (Resolution No. 25.648. Specific Rules for } \\
\text { Actuaries). }\end{array}$ \\
\hline Assessment & LO \\
\hline Comments & $\begin{array}{l}\text { Under the existing insurance legislation, insurance companies are not obliged to } \\
\text { undertake regular stress testing. SSN should design a stress testing program and ask the } \\
\text { companies to carry out such tests every year. These stress tests should encompass an } \\
\text { assessment of the adequacy of capital resources in the event technical provisions have } \\
\text { to be increased. } \\
\text { There is a concern (yet to be proven) in the insurance market that, as a result of fierce } \\
\text { competition there may be cases where companies do not maintain an adequate level of } \\
\text { technical reserves. SSN should prepare new standards respecting the provisions for } \\
\text { technical reserves which will provide greater confidence in the adequacy of liabilities. } \\
\text { The introduction of risk-based supervision would assist SSN in identifying any such } \\
\text { situations and provide the means for remedying the situation. }\end{array}$ \\
\hline Principle 21. & $\begin{array}{l}\text { Investments } \\
\text { The supervisory authority requires insurers to comply with standards on } \\
\text { investment activities. These standards include requirements on investment policy, } \\
\text { asset mix, valuation, diversification, asset-liability matching, and risk } \\
\text { management. }\end{array}$ \\
\hline Description & $\begin{array}{l}\text { The investment policy of insurance companies is regulated by the Insurance Law } \\
20,091 \text { (Article 35) which prescribes the type of assets that can be used to cover } \\
\text { technical reserves. The regulation sets restrictions on the amounts (in percentage of } \\
\text { technical provisions) that may be held in particular types of financial instruments. } \\
\text { Technical provisions may be invested in the following a) state and provincial bonds, b) } \\
\text { foreign state bonds up to the value of the liabilities contracted in the currency, c) private } \\
\text { bonds and debentures, d) loans and mortgages on assets in Argentina (maximum } 45 \% \\
\text { and, combined with real estate, a maximum of } 70 \% \text { ), e) real estate in Argentina } \\
\text { (maximum } 60 \% \text { and, combined with loans, a maximum of } 70 \% \text { ), f) shares of domestic } \\
\text { and foreign companies quoted on the Argentinean or foreign stock exchanges, e) loans } \\
\text { backed by bonds, shares and debentures as specified above, g) financial operations } \\
\text { guaranteed totally by banks and other financial organizations authorized to operate in } \\
\text { Argentina. } \\
\text { Although in the regulations, dealing with investments is not used to refer to the senior } \\
\text { person responsible for executing the investment policy, in the Regulations on Insurance } \\
\text { Activity, the 'Rules on Investment Policy and Procedures' must (among other several } \\
\text { issues) identify the people responsible for the execution of the investment policy. } \\
\text { Likewise, the 'Rules on Investment Policy and Procedures' must contain definitions on } \\
\text { the internal control policies to be applied in terms of investments and identification of }\end{array}$ \\
\hline
\end{tabular}




\begin{tabular}{|c|c|}
\hline & $\begin{array}{l}\text { the persons responsible for the implementation of said controls. Both the senior person } \\
\text { responsible for the execution of the investment policy defined in the Rules and the } \\
\text { senior person responsible for the internal controls on said transactions have to have } \\
\text { managerial rank or be members of the Board. In addition, the staff assigned to these } \\
\text { transactions has to be duly notified of the existence of such Rules. In its ordinary } \\
\text { meetings, the Board should examine, at least on a quarterly basis or more frequently, } \\
\text { depending on the circumstances or if the SSN considers it necessary, the compliance } \\
\text { with the "Rules on Investment Policy and Procedures" and must record in the respective } \\
\text { minutes the conclusions arrived at in said evaluation, any deviations observed and the } \\
\text { measures implemented to address them. These meetings must also approve specifically, } \\
\text { with details of the instruments comprised, the investments made by the company and } \\
\text { must provide instructions for future transactions in each specific aspect. } \\
\text { On the other hand, the regulations in terms of investment establish restrictions that have } \\
\text { to be maintained, which are not only those establishing limits to investments with } \\
\text { related parties, but also others which limit the total investments and available funds } \\
\text { abroad and those made in admissible loans and real estate for rental or own use. Also } \\
\text { compliance with rating requirements, custodial regime, etc. } \\
\text { The Resolution } 31.231 / 2006 \text { established minimum compulsory guidelines to develop } \\
\text { the "Rules on Administrative Procedures and Internal Controls", among the } \\
\text { requirements to be met in terms of Minimum Procedures: several operating circuits to } \\
\text { develop such minimum compulsory procedures, including those referring to Investment } \\
\text { Policies and Procedures. }\end{array}$ \\
\hline Assessment & $\mathrm{LO}$ \\
\hline Comments & $\begin{array}{l}\text { The risk management systems must cover the risks associated with investment activities } \\
\text { that might affect the coverage of technical provisions and/or solvency margins (capital). } \\
\text { The main risks include: } \\
\text { - market risk } \\
\text { - credit risk } \\
\text { - liquidity risk } \\
\text { failure in safe keeping of assets (including the risk of inadequate custodial } \\
\text { None of the above mentioned risks are clearly defined in the existing regulations. } \\
\text { The SSN should require that insurers have in place rigourous audit procedures that } \\
\text { include full coverage of their investment activities to ensure the timely identification of } \\
\text { internal control weaknesses and operating system deficiencies. If the audit is performed } \\
\text { internally, it should be independent of the function being reviewed. }\end{array}$ \\
\hline Principle 22. & $\begin{array}{l}\text { Derivatives and similar commitments } \\
\text { The supervisory authority requires insurers to comply with standards on the use of } \\
\text { derivatives and similar commitments. These standards address restrictions in their use } \\
\text { and disclosure requirements, as well as internal controls and monitoring of the related } \\
\text { positions. }\end{array}$ \\
\hline Description & NA \\
\hline Assessment & \\
\hline Comments & \\
\hline
\end{tabular}




\begin{tabular}{|l|l|}
\hline Principle 23. & $\begin{array}{l}\text { Capital adequacy and solvency } \\
\text { The supervisory authority requires insurers to comply with the prescribed solvency } \\
\text { regime. This regime includes capital adequacy requirements and requires suitable forms } \\
\text { of capital that enable the insurer to absorb significant unforeseen losses. }\end{array}$ \\
\hline Description & $\begin{array}{l}\text { Regulation 31.134 of 9 June } 2006 \text { established the minimum capital requirements for all } \\
\text { companies with effect from accounting year beginning } 1 \text { July } 2006 .\end{array}$ \\
Capital; The minimum capital that applies is the greatest of the following three \\
calculations a) by class of business, b) based on premiums, c) based on claims.
\end{tabular}

\section{Solvency Margins}

- For Non-life: In the same regulation that increased levels of capital, changes were made to the formulae for calculating solvency margins. The calculations are made on the following bases:premium basis $-16 \%$ of premiums plus surcharges of the previous 12 months adjusted by a co-efficient (never less than $50 \%$ ) calculated as the ratio of the net paid claims to gross paid claims of the previous 36 months

- claims basis - $23 \%$ of the incurred losses of the previous 36 months' period adjusted by a co-efficient calculated as the ratio of the net paid claims to gross paid claims of the previous 36 months.

The higher of the two calculations represents the required solvency margin.

For life:

- premium basis - $18 \%$ of the first ARS 5mn (USD 1.37mn) plus $16 \%$ on premiums over that figure

- loss basis - of the one-year average of the total claims of the last three years, $26 \%$ is applied to the first ARS $3.5 \mathrm{mn}$ (USD 956,284) plus $23 \%$ on losses above that figure. 


\begin{tabular}{|c|c|}
\hline & $\begin{array}{l}\text { The higher of the two calculations represents the required solvency margin. } \\
\text { The calculations for life business involving savings are the sum of the calculations } \\
\text { described below. } \\
\text { - In the first place } 4 \% \text { of the total mathematical reserves for direct and } \\
\text { reinsurance is multiplied by the relationship between the reserves that are } \\
\text { brought forward and the aforementioned totals. In no case should the difference } \\
\text { be less than } 85 \% \text {. } \\
\text { - Secondly } 3 \% \text { of the total sums insured of current policies is multiplied by the } \\
\text { relationship between sums assured brought forward and the aforementioned } \\
\text { sums assured. In no case should the difference be less than } 50 \% \text {. } \\
\text { At present, the minimum capital requirements are somewhat sensitive to the risk } \\
\text { insured, as they take account of the classes of business being written, but they can not } \\
\text { be said to be sensitive to the size of the insurer's operations. The solvency margin } \\
\text { requirements are sensitive to the size of an insurer, but can not be said to be sensitive to } \\
\text { the risks. }\end{array}$ \\
\hline Assessment & 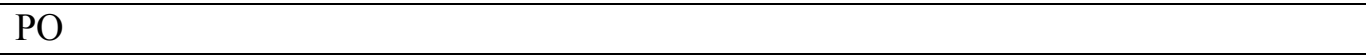 \\
\hline Comments & $\begin{array}{l}\text { Currently capital and solvency requirements are not adequately sensitive to the size of } \\
\text { the insurer and the risk of the insurer. The margin of solvency is computed by a formula } \\
\text { that resembles EU Solvency I. } \\
\text { The SSN should focus in the near future on the introduction of a risk-based capital } \\
\text { formula, such as those being followed in North America and various other jurisdictions. } \\
\text { There are no solvency control levels that would allow an effective operation of an early } \\
\text { warning system. The regulator issues a warning to companies only when the minimum } \\
\text { solvency ratio falls below the minimum prescribed threshold. }\end{array}$ \\
\hline \multicolumn{2}{|c|}{ Markets and consumers } \\
\hline Principle 24. & $\begin{array}{l}\text { Intermediaries } \\
\text { The supervisory authority sets requirements, directly or through the supervision of } \\
\text { insurers, for the conduct of intermediaries. }\end{array}$ \\
\hline Description & $\begin{array}{l}\text { The legislation requires insurance brokers to be registered. There are various } \\
\text { registration requirements, including commercial and professional knowledge. These } \\
\text { qualities are tested during exams organized by SSN. Once registered, brokers are } \\
\text { required to give customers information on their status, especially on their relationship } \\
\text { with particular insurance companies. The insurance broker is obliged to be independent } \\
\text { and contracts on cooperation between the insurance broker and the insurance companies } \\
\text { are prohibited. } \\
\text { There is no cap on commission paid by insurance companies to intermediaries, for both } \\
\text { long and short term insurance products. } \\
\text { Although insurance brokers are not required to have professional indemnity insurance, } \\
\text { in accordance with Regulation } 29.652 \text { of } 2003 \text {, reinsurance brokers are obliged to take } \\
\text { professional indemnity cover with a minimum limit of USD 1mn. } \\
\text { AAPAS is the local broker association. The largest brokers do not have representatives } \\
\text { on the board of directors. This is done in order to avoid accusations of using their } \\
\text { extensive market influence to determine the association's relations with the SSN and }\end{array}$ \\
\hline
\end{tabular}




\begin{tabular}{|c|c|}
\hline & $\begin{array}{l}\text { attitudes towards changes in legislation affecting brokers. } \\
\text { Market conduct examinations are carried out by SSN through on-site inspections. } \\
\text { Insurance brokers can be specialized in insurance or reinsurance activity. The company } \\
\text { acting as an insurance broker is obliged to employ specialists who have passed the } \\
\text { professional exam adequate to the scope of the activity. } \\
\text { If an insurance broker acts against the law, the SSN may revoke the insurance broker's } \\
\text { license or imposes sanctions. It is relevant to note that most premium payments by } \\
\text { individuals are remitted directly to the insurance companies. There does not appear to } \\
\text { be evidence of inordinate retention of premium monies by intermediaries. Therefore } \\
\text { insurance brokers usually do not handle their clients' money and they do not have to } \\
\text { protect it. } \\
\text { The marketing of insurance policies is mainly traditional, and the public still not very } \\
\text { familiar with the insurance products. This fact makes it necessary to explain products to } \\
\text { the clients. Brokers focus mainly on commercial business lines business, agents and } \\
\text { field sales representatives are competing with the alternative distribution channels for } \\
\text { the personal lines. Innovative approaches have been introduced since } 1998 \text {, the year in } \\
\text { which a small number of insurers made their first attempts at telemarketing. } \\
\text { Bancassurance: In the last couple of years, sales via banks have been growing most } \\
\text { strongly. Initially, this marketing channel was used primarily to sell non-life products } \\
\text { such as motor or fire insurance. In Argentina selling of insurance policies via banks } \\
\text { started with motor and fire insurance, but in recent years sales of life insurance products } \\
\text { especially have been increasing. } \\
\text { Selling insurance products through banks is as a rule beneficial for all concerned. The } \\
\text { client benefits from an ability to buy cheap and simple insurance products in his vicinity } \\
\text { and to pay his premiums in monthly installments. For the banks, selling insurance } \\
\text { products opens up a new source of income. Furthermore, the broader product makes the } \\
\text { bank more attractive and strengthens client loyalty. }\end{array}$ \\
\hline Assessment & $\mathrm{LO}$ \\
\hline \multicolumn{2}{|l|}{ Comments } \\
\hline Principle 25. & $\begin{array}{l}\text { Consumer protection } \\
\text { The supervisory authority sets minimum requirements for insurers and intermediaries in } \\
\text { dealing with consumers in its jurisdiction, including foreign insurers selling products on } \\
\text { a cross-border basis. The requirements include provision of timely, complete and } \\
\text { relevant information to consumers both before a contract is entered into through to the } \\
\text { point at which all obligations under a contract have been satisfied. }\end{array}$ \\
\hline Description & $\begin{array}{l}\text { Decree No. 1084/2004 approving the current Organic Structure of the SSN created the } \\
\text { Subdepartment of Community Relations. Its primary responsibility is; dealing with all } \\
\text { the issues related to the relations of the agency with the community and its institutions, } \\
\text { channeling and systematizing, in all cases, the enquiries and complaints made by users } \\
\text { and user organizations; and also dealing with the relations with the media. Its actions } \\
\text { include: attending and responding to enquiries made by the users of the insurance } \\
\text { system by any means. Receiving, processing and monitoring in full any claims and } \\
\text { complaints brought by users. Systematizing, taking into account the frequencies per }\end{array}$ \\
\hline
\end{tabular}




\begin{tabular}{|c|c|}
\hline & 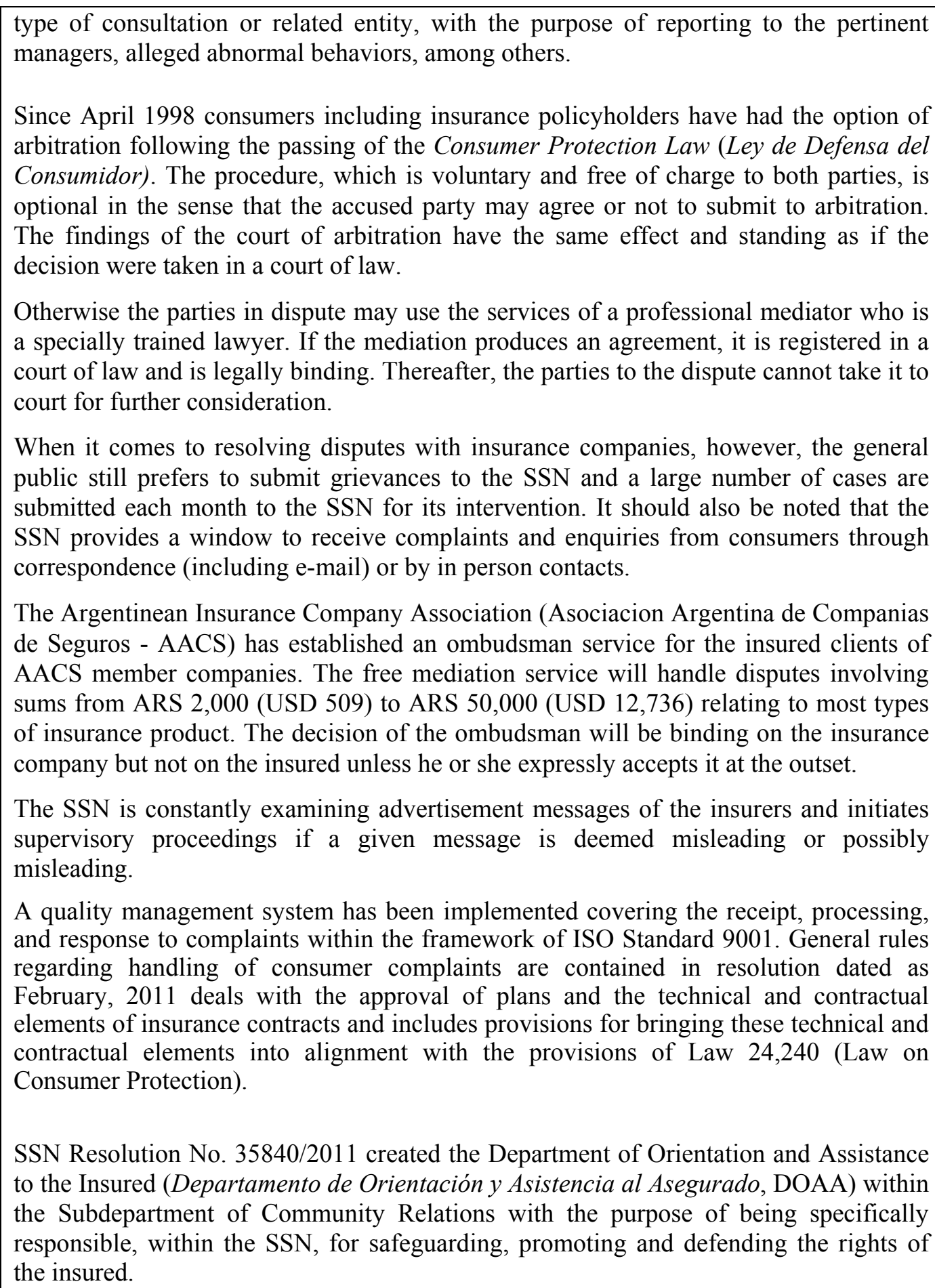 \\
\hline Assessment & LO \\
\hline Comments & $\begin{array}{l}\text { The SSN should require insurers and intermediaries to seek information from their } \\
\text { consumers that is appropriate in order to assess their insurance needs, before giving } \\
\text { advice or conculuding a contract. }\end{array}$ \\
\hline
\end{tabular}




\begin{tabular}{|c|c|}
\hline Principle 26. & $\begin{array}{l}\text { Information, disclosure \& transparency towards the market } \\
\text { The supervisory authority requires insurers to disclose relevant information on a timely } \\
\text { basis in order to give stakeholders a clear view of their business activities and financial } \\
\text { position and to facilitate the understanding of the risks to which they are exposed. }\end{array}$ \\
\hline Description & $\begin{array}{l}\text { Public disclosure requirements are comprehensive while the quarterly and annual } \\
\text { financial statements have to be submitted together with the External Auditor's Report, } \\
\text { with the signature certified by the corresponding Professional Council of Economic } \\
\text { Sciences. } \\
\text { SSN makes extensive information available through its own website in Spanish. } \\
\text { SSN Communications and Circulars also set standards for the presentation of } \\
\text { information by parties involved in the insurance market. For example: SSN Resolution } \\
30,490 \text { prescribes the presentation of balance sheets; SSN Circulars } 2,853 \text { and } 4,178 \\
\text { deal with reinsurance; } 25,188 \text { and its supplementary provisions address workplace risks; } \\
4,564 \text { contains regulations on automotive insurance; } 4,177 \text { presents criteria on } \\
\text { geographical distribution; } 3,384 \text { deals with the subject of monthly production, etc. } \\
\text {,The SSN stores information in databases, making it possible to publicly create series of } \\
\text { data and graphs to calculate the key financial indexes and parameters of } \\
\text { insurers.http://www.Ssn.gov.ar/storage/info-stadistica/aseguradoras/balances.htm }\end{array}$ \\
\hline Assessment & LO \\
\hline Comments & $\begin{array}{l}\text { The SSN should develop and maintain a set of ratios and data inputs from insurance } \\
\text { companies' reports that would allow market players and investors to analyze the } \\
\text { financial condition of insurers on a quarterly basis. In addition, the SSN should store } \\
\text { annual information in a database format to enable the public the creation of data series } \\
\text { and graphs for key financial parameters/ratios of insurers. }\end{array}$ \\
\hline Principle 27. & $\begin{array}{l}\text { Fraud } \\
\text { The supervisory authority requires that insurers and intermediaries take the necessary } \\
\text { measures to prevent, detect and remedy insurance fraud. }\end{array}$ \\
\hline Description & $\begin{array}{l}\text { Law 20,091 contains provisions for the punishment of insurance fraud that affects } \\
\text { insurers, policyholders, insurable parties, beneficiaries, and third parties that have } \\
\text { suffered damages. Circular 4,979 of September 19, } 2003 \text { established a database } \\
\text { information system for monitoring suspicious damage claims (Iris Program) for motor } \\
\text { insurance. } \\
\text { In addition, the SSN arranges for ongoing training activities designed to promote the } \\
\text { campaign against insurance fraud, with classes offered in various academic settings, } \\
\text { public and private institutions, NGOs, and universities in Argentina and elsewhere. } \\
\text { National legislation has specific provisions that address fraud. } \\
\text { The SSN has a multidisciplinary insurance fraud investigation group, which is not only } \\
\text { responsible for conducting training activities but has also disseminated a document with } \\
\text { information for the use of insurers in fighting fraud (Com. SSN No. 2.608 - } \\
\text { 18OCT2010), and has now completed the implementation of a questionnaire addressed } \\
\text { at the whole of the insurance industry, with the purpose of drawing a comprehensive } \\
\text { updated map of the modalities of insurance fraud (Com. SSN No. 2.826 - 03JUN2011). } \\
\text { Furthermore, when fraudulent practices are detected by it in the sector, the SSN issues } \\
\text { "Warnings to the Population" through mass communication media throughout the } \\
\text { country and its website. } \\
\text { SSN examines the issue of given types of crimes and specific activities, and also: }\end{array}$ \\
\hline
\end{tabular}




\begin{tabular}{|c|c|}
\hline & $\begin{array}{l}\text { - Has powers to deter, detect, record, report, and remedy insurance fraud. } \\
\text { - requires the adoption of internal oversight measures. } \\
\text { - } \text { requires insurance operators to take measures to combat fraud. } \\
\text { - has a database information system for the detection of suspicious or fraudulent } \\
\text { damage claims in the case of automotive insurance. } \\
\text { - cooperates with other authorities at the local level to combat fraud. }\end{array}$ \\
\hline Assessment & $\mathrm{LO}$ \\
\hline Comments & $\begin{array}{l}\text { The SSN should co-operate with other supervisory authorities including, as appropriate, } \\
\text { in other jurisdictions in countering fraud. }\end{array}$ \\
\hline \multicolumn{2}{|c|}{ Anti-money laundering, combating the financing of terrorism } \\
\hline Principle 28. & $\begin{array}{l}\text { Anti-money laundering, combating the financing of terrorism (AML/CFT) } \\
\text { The supervisory authority requires insurers and intermediaries, at a minimum } \\
\text { those insurers and intermediaries offering life insurance products or other } \\
\text { investment related insurance, to take effective measures to deter, detect and report } \\
\text { money laundering and the financing of terrorism consistent with the } \\
\text { Recommendations of the Financial Action Task Force on Money Laundering } \\
\text { (FATF). }\end{array}$ \\
\hline Description & $\begin{array}{l}\text { Even though the Insurance Law } 20,091 \text { (Law on Insurers and the Supervision thereof) } \\
\text { was enacted as early as } 1973 \text {, the Legislative Branch provided the SSN with a broad } \\
\text { technical platform and all the necessary attributions to exercise control over the } \\
\text { insurance and reinsurance business, as well as insurance intermediation, in a way that } \\
\text { transcends specific historical circumstances and, most importantly, takes into account } \\
\text { the particular dynamics of insurance activity. } \\
\text { When Law } 25,246 \text { (AML) gave the SSN the status of liable party (Sujeto obligado), the } \\
\text { Superintendence took on a new mandate beyond those given to it under Law 20,091. } \\
\text { Consequently, both its regulatory authority and its power to impose sanctions have been } \\
\text { extended to cover the laundering of assets and financing of terrorism. } \\
\text { Thus, although neither Law } 20,091 \text { nor Law } 25,246 \text { specifically empowers the SSN to } \\
\text { issue regulations to control the laundering of assets or the financing of terrorism, a } \\
\text { systematic interpretation of the two laws concludes without a doubt that it is authorized } \\
\text { to issue such regulations. And the issue has been resolved with the enactment of Law } \\
26.683 \text { of June } 1 \text {, 2011, which introduced reforms to Law } 25.246 \text { and substantial } \\
\text { changes in the regime on prevention and control of money laundering and terrorism } \\
\text { financing. } \\
\text { On the subject of interest, section } 14 \text {, par. } 7 \text { of the above mentioned law, empowers the } \\
\text { UIF to provide for the implementation of internal oversight systems for liable parties. } \\
\text { To that end, the UIF will establish the supervision, oversight and on site inspection } \\
\text { procedures to control compliance with the obligations established in section } 21 \text { of the } \\
\text { law and the guidelines and instructions issued in accordance with the powers granted by } \\
\text { section 14, par. } 10 \text {. Said section empowers the UIF exclusively to issue guidelines and } \\
\text { instructions that the liable parties will be required to comply with and implement. The } \\
\text { liable parties which, in turn, are supervision agencies (SSN, BCRA and CNV), will only } \\
\text { be able to issue standards of procedure which are "complementary" of the guidelines }\end{array}$ \\
\hline
\end{tabular}


and instructions issued by the UIF, and will not be able to expand or modify the scope defined in such guidelines and instructions.

This means that in the area of prevention and control of asset laundering, the Financial Information Unit (UIF) is the agency responsible for issuing the corresponding regulations and of the supervision, oversight, inspection and potential sanction of the Liable Parties.In the area of asset laundering prevention and control, SSN plays a double role: on the one hand as the control and supervision agency of the insurance activity and the other as a Liable Party required to report suspicious transactions to the UIF. Section 20 of UIF Res. 19/2011 provides that SSN, within the framework of the supervision and oversight practices, will provide the UIF with the necessary cooperation to evaluate compliance by the entities with the obligations resulting from section 21 the Law 25.246 as amended (due diligence regarding clients and prevention policy). That is, SSN only supervises compliance of the anti money laundering rules by insurers, in "cooperation" with the UIF, which is the agency expressly empowered by the law.

On the other hand, as a liable party required to report suspicious transactions to the UIF, the SSN should also adopt a prevention policy in terms of Asset Laundering and Terrorism Financing, which should at least contemplate the following aspects:

A manual of procedures, which will contain the mechanisms and procedures for Money Laundering and Terrorism Financing prevention, with the particularities of its activity.

The appointment of a Compliance Officer responsible for overseeing compliance and implementation of internal control procedures to prevent asset laundering and terrorism financing and who will also serve as liaison with the UIF.

\section{The implementation of periodic audits.}

\section{Training of personnel.}

The development of a written registry of the risk analysis and management regarding the suspicious transactions reported.

The implementation of appropriate technological tools, which make it possible to establish effectively the Asset Laundering and Terrorism Financing control and prevention systems.

The newly appointed Superintendent has taken a big step with to carry out this work with the issue of a SSN Resolution on April 2011 which has created the Coordination Unit on Anti-money Laundering and Combating the Financing of Terrorism (strike out within the scope of the Superintendent role), and designated an executive as Compliance Officer. Such Coordination Unit is in charge of implementing, coordinating and enforcing the policies set forth on that matter by the Superintendent of Insurance and UIF, according to legal and administrative rules in force and according to international recommendations.

The creation of the Department (Gerencia) on prevention of money laundering and the financing of terrorism within the formal structure of the National Insurance Superintendence is still pending ministerial approval.

The SSN is currently working in implementing an AML/CFT specialized supervision / oversight scheme, which is described below: 
- Planning the inspection activities in the insurance sector in accordance with a risk based approach.

- Establishing an inspection schedule based on a risk matrix of the insurance sector.

- Establishing specific procedures in each entity, derived from the analysis of the risk profiles of each insurer.

- Establishment of an inspection procedures manual which, among others, will comprise the following aspects:

- Evaluation of background of each insurer in this regard (in connection with sanctions, performance of internal and external auditors, information systems, etc.).

- Evaluation of the control environment in terms of AML/CFT.

- Evaluation of the computer environment and its implications in these matters.

- Evaluation of the monitoring controls of major transactions.

$\circ$ Evaluation and definition of various inspection strategies or a combination thereof (on site and/or off site).

- Definition of design tests of the internal controls in this area.

- Definition of compliance tests of the above mentioned controls (test requirements, evidence analysis, types of evidence, evaluation of test results, conclusions, etc.).

- Definition of substantive tests (nature and scope of each test, sample selection criteria, evaluation of results, conclusions, etc.).

- Sampling policies.

- Establishment of criteria for the preparation of working papers.

- Resolution of critical issues.

○ Reporting.

- Suspicious transactions reporting practices.

This scheme will allow the supervisor to conduct a strict specialized oversight regarding appropriate compliance of the AML/CFT regulations.

A risk based supervision scheme implies a methodology that enables an efficient application of resources in the implementation of supervision tasks, basing their inspection work on a risk based review approach.This scheme starts from a comprehensive and global vision of the business of the entities and their controls, which makes it possible to arrive at a preliminary finding regarding the entities' controls, and then develops the review process in each of the relevant accounting cycles. That is, it replaces the audit review approach based on the selection of accounting balances with a review approach based on the risks and controls existing in the relevant accounting cycles of the entities.

Such scheme consists of:

- On site supervision (inspection visit): planning, defined inspection procedures, field work, communication of findings and reporting, and,

- Off-site supervision: data management, evaluation of the entity's overall situation, risk exposure, stress tests, on demand reports, etc. 


\begin{tabular}{|c|c|}
\hline & $\begin{array}{l}\text { Use of support tools for the various stages in the supervision process. } \\
\text { Training activities for the supervisory team. } \\
\text { Specific AML/CFT Training Plan } \\
\text { The training plan will consist of the following activities, to be conducted by means of a } \\
\text { schedule: } \\
\text { - Basic AML/CFT training, for all SSN personnel. It will cover the basic } \\
\text { concepts of a prevention structure, as well as the main risks and typologies of } \\
\text { asset laundering and terrorism financing in the insurance sector. The first course } \\
\text { was carried out on } 07 / 12 / 2011 \text {. } \\
\text { Advanced AML/CFT training, for SSN officials on the implementation of the } \\
\text { Comprehensive Manual of Risk Based Supervision, on site, off site and } \\
\text { comprehensive supervision schemes. } \\
\text { Dissemination workshops to socialize the new supervision scheme within the } \\
\text { insurance sector. }\end{array}$ \\
\hline Assessment & LO \\
\hline Comments & $\begin{array}{l}\text { The creation of a Coordination unit is an excellent move in the right direction and this } \\
\text { new structure should be in place as soon as possible. And the implementation of a } \\
\text { specialized supervision / audit scheme on AML/CFT, which is described in the SSN } \\
\text { Strategic aspect on AML/CFT, should also be started. }\end{array}$ \\
\hline
\end{tabular}

\section{AUTHORITIES'S RESPONSES}

\section{A. Part I. Introduction}

It has been almost eleven years since Argentina's last engagement with International Organizations took place regarding a financial sector assessment. The FSAP conducted in 2001 was interrupted and suspended once the crisis entered in its worst stage and was never resumed. The world is currently witnessing a new phase of the systemic crisis that erupted in 2007 in advanced economies, which so far, has shown many phases and which consequences are being felt in every part of the globe.

The policy response to this crisis in central countries and the persistent uncertainty around future developments in the euro zone, has led to massive swings in capital flows, which have made it necessary to implement measures that attenuate their impact on the exchange rate and domestic monetary conditions.

In addition, Argentina's authorities found worrisome that the current strategies adopted by most countries in distress is being centered on fiscal consolidation and labor flexibility, instead of 
focusing in growth oriented policies, like the ones Argentina imposed after experiencing its worst crisis in decades. Furthermore, we are concerned about the fact that international organizations are recommending countries the same policy programs that were applied before in our country. If we have learnt something from the 2001/2002 crash is that, without programs aimed at promoting growth in aggregate demand, job creation and economic growth, debts become unsustainable and difficult to pay.

The authorities acknowledge that important challenges remain, and the assessments were noteworthy to identify many of them. The reinforcement of the supervision powers in accordance to international standards represents an immediate task. The effective identification, regulation and supervision of financial groups and/or conglomerates is presented transversally throughout the three assessments, and is a key challenge.

The report takes many elements under consideration while assessing the preconditions that each market should have so as to develop. Nevertheless, the mission arrives at some conclusions that need a more objective approach. In this line, the Authorities believe that the views regarding the pension system reform should be revised. Moreover, some points ought to be remarked and some processes further described in order not to fall under subjectivism, particularly regarding the facts and consequences of the State's recovery of the pension system management.

The 2001/2 crash left deep wounds, not only in an economic sense but also in the social and political spheres. The country's economy had been driven to unsustainability after years of, overall, current account and fiscal deficits and an increasing dependence on external financing of both the public and the private sectors. The lack of competitiveness, coupled with overindebtedness and an extremely rigid macroeconomic framework finally led to a financial debacle and to a dramatic unemployment rate of $21.5 \%$ in May 2002. The financial system collapsed and government institutions suffered a sharp down on credibility. Social instability impacts and consequences didn't take long to come out.

The economic policy framework applied during the decade before the crash, which was acclaimed and praised by International organizations, led the country to a point of no return, which no one (neither the Government, nor the International Organizations, and Credit Rating Agencies or consultants) could predict until the crunch became present, and with all type of warnings and downgradings nothing but prociclicality emerged.

Argentina started to recover when the Government put in place the backbone of a new macroeconomic architecture, characterized by abandoning convertibility and by implementing a flexible exchange rate regime, measures which, significantly, made it possible to recover the central bank's capacity to implement monetary policy and the institution's role as a lender of last resort. In parallel, getting primary and current account surpluses, tackling unsustainable public debt levels and composition (cancelling with the IMF and international creditors who were defaulted), and strongly underpinning social safety nets, made it possible to reacquire competitiveness and to reach a sustainable path of growth.

Figures from 2003 onwards show that Argentina's recovery was overarching, reflected by GDP growing hand in hand with job creation. This process has been achieved without any assistance 
from International organizations (in fact net disbursements were negative) and by, crucially, not heeding these institutions policy advise, which with the benefit of hindsite were definitly wrong. Needless to say, the sovereing debt restructuring was fundamental for Argentina's recovery and growth.

The inclusive growth path that Argentina started to transit would not have been possible to continue without recovering the administration of pension funds.

As mentioned before, the report arrives at certain conclusions that not only are influenced by a subjective or even dogmatic view, but also are simply wrong. In particular, the assertion that links the creation of the public countercyclical pension fund (Fondo de Garantía de Sustentabilidad-FGS-), with the lack of availability of long term financial resources for banks and other players, or with the low liquidity and depth of the capital markets needs to be reconsidered under the light of empirical data.

By analyzing the involvement of the Fund and the World Bank in the adoption and implementation of the flawed 1994 social security reform one can hint this involvement as being at the inception of one of the drivers of the ROSC characterization of the 2008 reversal, recovering the administration of the pension funds. In effect, the 1994 reform not only was continuously praised by the Fund and the World Bank, but also its adoption constituted a structural performance criterion for the program supported by the extended arrangement approved by the Fund in March 1992.

In this regard findings of the Independent Evaluation Office' Report on the Evaluation of the Role of the IMF in Argentina 1991-2001 (Chapter 2 Surveillance and Program Design) are telling ${ }^{8}$.

One of the main unfulfilled promises of the 1994 reform was that the private administrators (AFJPs) would contribute to the stock markets development. Between June 2000 and June 2007, before the onset of the global financial crisis, the balance managed by the AFJPs was multiplied

8 “... The fiscal imbalance created by the social security reform was significant. From 1994 on, government revenues from social security payroll taxes gradually declined, with the revenue gap in 2001 estimated at 2.9 percent of GDP. Of this, 1.5 percent was due to the transfer of workers' contributions from the social security system to individual accounts in the new private pension funds, a direct effect of the reform, and the remaining 1.4 percent resulted from the reductions in payroll tax rates. On top of this, the federal assumption of the liabilities of the provincial systems added another 0.9 percent of GDP annually to expenditures by 2001. Against this, there were offsetting reductions in social security expenditures as a result of the reform; an estimate by Rofman (2002), which may be optimistic, is that annual expenditures were smaller by 1.1 percent of GDP in 2001. Taken together, the reform and accompanying policy changes worsened the annual overall fiscal balance of the federal government by at least 2.7 percent of GDP.

The role of the IMF: The social security reform was initiated and in large part designed by the Argentine authorities, with the World Bank providing some technical assistance. In retrospect, most observers (the IMF, the World Bank, local commentators, and the administrators of the new private funds) overemphasized the potential benefits of the new system and failed fully to anticipate its severe fiscal consequences. Part of the problem was that it overestimated the self-financing component of the reform, without recognizing the imperfections of capital markets that would create an immediate burden on the government's borrowing requirements. The increase in fiscal deficits arising from the reform was considered simply as an explicit recognition of already existing implicit debt, which the markets should be willing to finance..." 
five-fold, from $\$ 18,714$ to $\$ 95,871$ million and the ratio Balance of the Retirement Fund/GDP rose 1.8 times, from $6.4 \%$ to $11.5 \%$. However, in the same period the domestic market capitalization was multiplied only 3.5-times, from $\$ 51,979$ to $\$ 179,771$ million, and in terms of GDP it increased only by 1.3 times, from $17 \%$ to $22 \%$. Figures from December 2011 , show that financing through the local capital market grew by 3.6\% y/y. In comparison to 2009 and 2008, was $108 \%$ and $92 \%$ above them respectively 9 .

What's more, its important to analyze the effect that administration fees and insurance premiums which the AFJPs charged their affiliated have over the development of the markets. Those fees as well as premiums for insurance accounted, in average, $35 \%$ of the contribution made by the affiliated workers per month. This fact was provoking significant asymmetries between nominal gross profits presented in the AFJP's balance sheets and what was actually reflected in the workers capitalization accounts. Between 1994 and 2008 the AFJP's gross notional revenue average reached $8.27 \%$ while the income after fees and premiums was $2.4 \%$. As an immediate consequence, the pension funds had less availability of liquidity to invest, affecting the individual workers account. Since the pension system returned completely to public management, no fee or premium is collected, allowing the FGS to have more resources available to invest and a more rapid growth of capital. In fact, AFJP's funds presented a growing trend since 1994 (when they were created) accounting 13\% of GDP in June of 2007. Between 2008 and 2011 the FGS' capital went from \$ARS 98.000 to \$ARS 199.490, reaching 10.2\% of GDP, figures that reflect a more rapid growth than the AFJPs could get in a period of 13 years since their creation in 1994.

Effective Profit for Affiliated Workers, 1994 - 2008*

Profits from incomes after management fee

\begin{tabular}{|l|c|c|}
\hline \multirow{2}{*}{} & \multicolumn{2}{c|}{ AfJul Rate of Return } \\
\cline { 2 - 3 } & Nominal & Effective \\
\hline Arauca Bit & $8,28 \%$ & $2,41 \%$ \\
\hline Consolidar & $9,25 \%$ & $3,33 \%$ \\
\hline Futura & $7,92 \%$ & $2,07 \%$ \\
\hline Máxima & $8,58 \%$ & $2,69 \%$ \\
\hline Met ${ }^{\star *}$ & $8,93 \%$ & $3,02 \%$ \\
\hline Nación & $10,97 \%$ & $4,95 \%$ \\
\hline Orígenes & $7,98 \%$ & $2,12 \%$ \\
\hline Previsol & $8,89 \%$ & $2,98 \%$ \\
\hline Profesión + Auge & $8,09 \%$ & $2,23 \%$ \\
\hline Unidos & $7,55 \%$ & $1,72 \%$ \\
\hline AVERAGE & $\mathbf{8 , 2 7} \%$ & $\mathbf{2 , 4 0} \%$ \\
\hline
\end{tabular}

Assumption: A worker that start into the system in 1994 , with a salary of $\$ 1.000$, adjusted since 2001 . This calculation was made in October 2008, near the half of the 30 years old worker's horizon. The attribution of the AFJP's fee as a \% of the total worker contribution decreases during the time

In addition, since the FGS was born, the resources previously managed by private pension funds started to be invested in a vast kind of infrastructure projects, including roads, energy and social

\footnotetext{
${ }^{9}$ See the chart in CNV's DAR.
} 
housing, mainly through the capital market. By November 2008, the private pension system had invested just $0.63 \%$ of their assets in project financing. Those investments were allocated only in two projects, one of which represented $96 \%$ of the total. Today, under the investment policies described, the FGS enhanced the previous scheme of investment in relation with longer terms and a more effective impact on the real economy, taking the infrastructure and developing share of the Fund portfolio up to $13.9 \%{ }^{10}$ by December 2011, given, since 2008, a context of global crisis where confidence in financial markets is at stake.

Regarding the availability of funding for the banking sector, we must note that the FGS augmented its share of term deposits in banks from $9.1 \%$ at it inception to an average of $11 \%$ in the period December 2011 - April 2012, maintaining at the same time a significant degree of diversification. In addition, the FGS launched open auctions to allocate its deposits, where the best bank offer would result in the cheapest financing to small and medium enterprises productive projects.

In conclusion, with respect to the depth of the domestic capital market, we must say that the Argentine stock market has historically been small in relation to GDP. Moreover, it has always had a limited degree of diversification across sectors and a low number of listed companies. In addition, the exceptional macroeconomic instability suffered by the country after WWII has generated a pattern of behaviour on the part of economic agents that has for a long time been part of our "culture", a factor which exacerbates the domestic repercussion of any negative external development. Consequently, to blame the creation and operation of the FGS for the adverse evolution of the local stock market in 2008/2009 is a mistake. The evolution of the depth and liquidity of the local stock market has been affected by structural and hystorical factors; nothing has to do with the creation of the FGS in 2008. On the contrary, investment policies taken by the FGS were aimed at boosting long term financing through the banking sector and the stock exchange market, by supporting the developing of both. Penetration in relation to GDP has never been over $20 \%$, being particularly affected by the 2001/2002 collapse, which has had a profound impact on the collective memory of economic agents.

Concerning statistics, the Authorities want to remark that the institutions involved in the ROSC processes use only data provided by the National Institute of Statistics and Censuses (INDEC), an institution which has elaborated and published statistics in Argentina since 1968; no province or private agency has the ability or the resources to publish a representative CPI index. Notwithstanding, the Government is currently in the process of developing an enhanced CPI index with the technical assistance of the IMF. This new indicator will have, for the first time a national coverage and will collect data from all over the country, in contrast to the current index, which is constructed based on data from the city of Buenos Aires and the Greater Buenos Aires area.

\footnotetext{
${ }^{10}$ We should highlight that investments in public instruments (including debt issued by public entities) remain at similar levels in relation with the holdings managed by the AFJPs; in average, all AFJPs had a share of $54.4 \%$ of their portfolio invested in public instruments by November 2008, while the FGS held by December 2011 public assets which represented $58.2 \%$ of its investments.
} 


\section{B. Part. II. Detailed response to the principles adherence assessment.}

\section{IAIS PRINCIPLES FOR INSURANCE SUPERVISION SUPERINTENDENCIA DE SEGUROS DE LA NACIÓN}

Our comments to some conclusions of the Detailed assessment are as follow.

ICP 1: The SSN dictated the Resolution 39.350/2011 which establishes a new capital adequacy framework for the insurance industry. The WB is provinding a technical assistance aimed at developing a more risk based approach for supervising, including the implementation of early warning systems.

ICP 3: The Supervisory Authority in this regard has implemented the PIEC (Incentive Programme for Education and Training). The PIEC currently allows a substantial improvement in the income of officials and employees of the SSN.

There are also ongoing training programmes for employees of the SSN, including training inside and outside the agency. There are various agreements signed by the State, for which the employees and officers of the SSN can be trained free of charge at public and private universities both in the country and abroad.

ICP 4: Our insurance legislation (Section II of the Law 20,091) allows an Advisory Council composed of 5 members of insurance companies, which assists the Superintendent.

ICP 5: MoUs have been signed with the SEFyC and the CNV, which are in force and in operation. Additionally, a MoU has been recently signed with the Insurance Superintendence of Brazil and another MoU is in analysis and will be signed between the members of ASSAL.

ICP 18: The second technical assistance of the World Bank that will take place the second half of 2012 plans to work specifically on this subject.

ICP 26: The SSN's webpage disclose rates, rankings, and other information about insurers and reinsurers (operating or in liquidation), including balance sheets, shareholders and board composition, etc.

Additionally, the SSN has implemented a digital system that allow the insured to know the status of their insurance policy on-line and check if others are under coverage. Also the SSN can control the clauses. It was first mandatory for the companies operating in the automobile market because it is the largest, but in the future it will include all other types of insurance.

ICP 27: The SSN have signed a MoU with the Superintendence of Insurance of Brazil in April. And also there are plans to sign MoU with other countries of ASSAL.

ICP 28: There is a new Coordination Unit working together with UIF (Financial Information Unit) to coordinate the AML/CFT framework in the insurance industry and implement FATF recommendations. On site inspections are running (21 companies in 2011). 